\title{
Millet Mekteplerinin Halk Eğitimi Açısından İncelenmesi
}

\section{To Examine of Nation Schools from the Perspective of Public Education}

\author{
Fezade BAYRAKTUTAN ${ }^{1}$ (i)
}

'Doktora Öğrencisi, İstanbul Üniversitesi, Atatürk İlkeleri ve İnkılap Tarihi Enstitüsü, İstanbul, Türkiye

\section{ORCID: F.B. 0000-0002-9160-6539}

Sorumlu yazar/Corresponding author: Fezade Bayraktutan,

İstanbul, Türkiye

E-posta/E-mail:

fezade@hotmail.com

Başvuru/Submitted: 26.04.2019 Revizyon Talebi/Revision Requested: 17.04.2020

Son Revizyon/Last Revision Received: 27.04.2020

Kabul/Accepted: 12.05 .2020

Atıf/Citation: Bayraktutan, F. (2020). Millet Mekteplerinin Halk Eğitimi Açısından İncelenmesi. Yakın Dönem Türkiye

Araştırmaları-Recent Period Turkish Studies, 37: 119-150.

https://doi.org/10.26650/YTA2020-005
ÖZ

Türkiye'de 1928 yılında Arap harflerinden oluşan alfabe terk edilerek Latin harflerine dayanan yeni bir alfabe kabul edildi. Bu inkılap sonrası yeni alfabenin halka öğretilmesi amaciyla Millet Mektepleri kuruldu. Millet Mektepleri 1 Ocak 1929 tarihinde resmen faaliyete geçti ve bu ilk dönemde edinilen bilgilere göre bazı yeni düzenlemeler yapılarak 1 Kasım 1929 tarihinde ikinci dönemi açıldı. Çalışmanın amacı, Millet Mektepleri'nin bir eğitim kurumu olarak incelenmesi ve halk eğitimine katkılarının değerlendirilmesidir. Çalışmada, Harf İnkılabı'na kısaca değindikten sonra Millet Mektepleri teşkilatı incelenmiş sonra da halk eğitimine katkıları tartışılmıştır. Çalışma sırasında arşiv belgeleri, gazeteler, Meclis Tutanakları, basılı kaynaklar ve Millet Mektepleri'nde okutulan kitaplar kaynak olarak incelenmiştir. Özellikle ders içeriği konusu Millet Mektepleri’nden beklenenin ortaya konması amaciyla Millet Mektepleri talimatnamesinden yararlanılarak hazırlanmıştır. Millet Mektepleri'nin ilk ve en önemli katkısının yeni alfabenin duyurulması ve tanıtılması olduğu söylenebilir. Bu aynı zamanda yeni bir dönemin de duyurulmasıdır. Millet Mektepleri ayrıca ülkedeki okuryazar oranının artmasına, halk eğitiminin daha kurumsal bir yapı kazanmasına da yardımcı olmuştur. Millet Mektepleri'nin ve okuma odalarının daha sonra açılacak Halkevleri ve Halk Odaları için birer prova niteliği taşıdığı da söylenebilirr.

Anahtar Kelimeler: Halk Eğitimi, Harf İnkılabı, Millet Mektepleri

\section{ABSTRACT}

The alphabet which was formed with Arabic Letters was abandoned and replaced with a new alphabet based on Latin letters in Turkey in 1928. After this revolution, the Nation Schools were founded for the purpose of teaching the new alphabet to the public. The Nation Schools were officially activated on January 1,1929 . Its second term opened by making some arrangements for new experiences which it had earned in the first term. The aim of this study are to 
examine in detail the Nation Schools as an education institution and to argue about its assistance to public education. In the study, after the Alphabet Revolution, Nation Schools were examined as an institution and finally the contribution to public education was examined. Archive documents, newspapers, The Turkish Grand National Assembly Records, books, articles, and textbooks of Nation Schools were used during the study. The lesson content was prepared using The Nation Schools regulations book to show what the educational expectations were for the Nation Schools. The first and most important contribution of Nation Schools were to announce and introduce the new alphabet. At the same time, it was an announcement of a new era. The Nation Schools contributed to an increased rate of literate students and helped public education have more structure. Nation Schools and Reading Rooms were the precursor for the Nation Houses and Rooms which would open a couple of years later.

Keywords: Public Education, Alphabet Revolution, Nation Schools

\section{Extended Abstract}

On November 1, 1928 a new alphabet was accepted in Turkey. After this revolution, Nation Schools were activated to teach the new alphabet to the Turkish people to make them literate. The Prime Minister, İsmet İnönü, described the Nation Schools as an initiative to rescue the people from ignorance.

Through the Nation Schools, reading and writing was taught to people without any setback in their daily activities and work. Nation Schools started education programs on January 1, 1929. After extensive publicity campaigns, the Nation Schools were the scene of enthusiastic openings.

A new mission was created in the second term; new lessons would be given in addition to teaching reading and writing. The aim was to provide some basic information to the people.. For that reason, it began to give new lessons such as health, counting and measurement, and homeland information.

Lessons were six hours per week and students were 16-45 years old. There were two types of Nation Schools, itinerant and settled. Itinerant Nation Schools would give service for the areas which had no schools. A book which contained the constitution would be given as a present to the first three students that obtained the best degrees. There were two classes in Nation Schools, A and B classes. The content of A classes was reading, writing, and numbers. In the $\mathrm{B}$ classes, counting and measurement, health, and homeland information would be taught. Lessons and their time periods per week were:

Reading and writing - two hours, Counting and Measurement - two hours, Health one hour, and Homeland Information - one hour. 
The reading lesson intended to teach easy reading to make students love to read. The Writing Lesson's aim was to teach students how to write their ideas and thoughts clearly. Such topics as counting, measuring units, and four operations were taught in Counting and Measurement. The Health Lesson's first aim was to give basic information about the body, organs, and their functions. Secondly, to teach individual and social health essentials. Homeland Information included titles like basic Turkish History, the Republic, the Turkish Grand National Assembly, elections, the president of the republic, local governments, taxes, the military profession, and national holidays.

In February 1929 the Ministry of Education published a magazine called "Public" to encourage people's reading habit. Also, the Ministry of Education published some special alphabets and books and distributed them for free. The reading rooms were opened to continue people's reading habit. Finally, Village Boarding Classrooms were designed for villages which did not have any schools.

Nation Schools were under province management as noted in the regulations book. Money was set aside from the education part of a province budget for Nation Schools. How many schools that opened in an area was dependent on the provincial government.

Nation Schools failed to carry on its success for the long term. Economic factors played a role in this situation. There was a difference of opinion between the Ministry of Education and the Ministry of Finance. Also, the 1929 economic crisis affected both the economy and agenda of the country. In the first five years, 1.2 million people graduated from Nation Schools. This is an important result to take into consideration. But, the most important contribution of Nation Schools was the introduction of the new alphabet. Nation Schools contributed to an increased rate of literacy and helped public education to have more structure. The Nation Schools and Reading Rooms were the precursor for Public Houses and Rooms which would open a couple of years later. 


\section{Giriş}

Osmanlı İmparatorluğu'nda ilk defa, Tanzimat Döneminde eğitim ve yazım sorununun artması ile birlikte aydın-bürokrat çevrelerinde mevcut alfabenin yetersizliği ile ilgili tartışmalar dile getirilmeye başlanmıştı. Tanzimat dönemiyle bir modernleşme sürecine girmiş olan Osmanlı İmparatorluğu'nda; bürokratik merkeziyetçilik ve yaygın eğitim çabaları, kullanılmakta olan imlayı bir sorun haline getirmiş, bunun üzerine de yazıyla ilgili tartışmalar başlamıştı. ${ }^{1}$

Bu dönemde geri kalmışlığın nedenleri arasında, başta kullanılan Arap alfabesi gösterilmiş ve bu yüzden de alfabede bazı değiş̧ikliklerin yapılması gerektiği öne sürülmüştü. Münif Paşa'dan Azerbaycanlı edebiyatçı Mirza Fethali Ahundzade'ye, Ali Suavi'den Namık Kemal'e, Gaspıralı İsmail Bey'den Ebuzziya Tevfik'e kadar dönemin en önemli aydınları bu tartışmalara bizzat katılmışlardı. ${ }^{2}$

Henüz 1853 yılında İbrahim Şinasi Efendi harflerde bazı işaretlerle düzeltmeler yaparak dört yüz kadar olan matbaa harfleri kasasını 112'ye indirerek ıslahat fikrini uygulama safhasina koyuyordu. ${ }^{3}$

1862'de Münif Efendi ilk kez Arap yazısının okuryazarlığı kösteklediği ve cahilliğin yaygınlaşmasına yol açtığı fikrini ortaya atmıştı. Bundan iki yıl sonra Azerbaycanlı Fethali Ahunzade ya da Ahundov Osmanlı bilim kuruluna bir proje sundu. Projesinin başlıca fikirleri, cahilliğin başlıca sebebinin Arap yazısı olduğu, Arap yazısı kullanmanın bir din işi olmadığı, yeni bir yazı benimsenmesinin dini açıdan sakınca oluşturmayacağı ve yeni yazıya geçiş sürecinde eski yazının kullanılmaya devam edilebileceği şeklindeydi. ${ }^{4}$

Yine aynı dönemde Latin harfleri yavaş yavaş Türk basın hayatına girmeye başladı. Latin harflerine, gazete ve dergi başlık ve lejantlarında, batılı yazarlardan yapılan alıntılarda, terimlerde, yerli ve yabancı özel isimlerde ve yabancı şirketlerin ilan ve reklamlarında posta pullarında rastlanmaktaydı. Latin harflerinin yaygınlaşmasında, azınlıkların çıkardığı Latin harfli gazetelerin de etkisi olmuştu. ${ }^{5}$

\footnotetext{
Fahri Kılıç, "Yeni Türk Alfabesinin Kabulü ve Öğretiminde Kullanılan Yöntemler-Araçlar”, Yayımlanmamış Doktora Tezi, Ankara Üniversitesi Türk İnkılap Tarihi Enstitüsü, Ankara, 2011, s.18.

2 Seda Bayındır Uluskan, Atatürk'ün Sosyal ve Kültürel Politikalarl, Ankara, Atatürk Araştırma Merkezi, 2010, s.187.

3 Tanzimat tan Cumhuriyet'e Alfabe Tartışmaları, yay. haz. Hüseyin Yorulmaz, İstanbul, Kitabevi, 1995, s.357.

4 Niyazi Berkes, Türkiye 'de Çağdaşlaşma, 7. Baskı, İstanbul, Yapı Kredi Yayınları, 2005, s.264-265.

5 Tanzimat'tan Cumhuriyet'e..,s.357. Fahri Kılıç, Yeni Türk Alfabesinin..., s.14.
} 
Alfabe ile ilgili tartışmalar Alfabenin ıslahının yeterli olduğu ve tamamen değiştirilmesi gerektiği noktalarında yoğunlaşıyordu. ${ }^{6}$ Şinasi, Namık Kemal ve Suavi gibi dönemin önemli aydınları da alfabede düzeltmeler yapılmasına sıcak bakıyorlar fakat Latin harflerine karşı çıkıyorlard $1^{7}$.

Osmanlı Devleti'nde Batıcılar olarak bilinen ve görüşlerini daha çok İçtihat Mecmuası'nda yayınlayan aydınlar programlarında “Mevcut elifbayı Osmanî atılarak yerine Latin harfleri kabul edilecektir" demekteydiler. Bu akımın önemli isimlerinden Celal Nuri (İleri) de "Tarih-i Tedenniyat-i Osmaniye" adlı eserinin "Edebiyat Meselesi" başlığı altında Arap alfabesinin yetersizliğinden bahsederek, ilerlemeye engel olduğunu ve büyük bir cesaretle Latin Alfabesinin kabul edilmesi gerektiğini savunuyordu. ${ }^{8}$

Alfabe tartışmalarının iyice yoğunlaştığı II. Meşrutiyet döneminde Abdullah Cevdet, İçtihad dergisi ile kitaplarında Romen rakamları kullanmaktayd1. ${ }^{9}$ Birinci Dünya Savaşı'ndan önce “Tanin” gazetesinin birinci sayfasında Harbiye Nazırı Enver Paşa'nın yeni yazı denemeleri yer almaktaydı. Enver Paşa kendi dairelerinde Türk yazısını değiştirmişti. Yeni yazıda bitişik harf usulü kaldırılmış, imla harfleri üzerine hareke konmuştu. Hatta resmî nezaket tezkereleri yeni yazı ile yazılmaktaydı. ${ }^{10}$

I. Dünya Savaşı'nın sona ermesi ve Türk Kurtuluş Savaşı'nın başarıyla sonuçlanmasının ardından alfabe tartışmaları devam etmişti. Nitekim, Millî Mücadele sonrasıLatin harfleri ile ilgili ilk tartışma İzmir'de yapılan İktisat Kongresinde İşçi delegelerinden İzmirli Nazmi ve iki arkadaşının verdiği önerge ile gündeme getirilmişti. Kazım Karabekir Paşa aynı kongrede yaptığı konuşmada bu fikre karşı olduğunu açıklamıştı.

Ancak alfabe meselesi, Lozan Antlaşması'ndan sonra, 25 Şubat 1924'te TBMM'de bütçe görüşmelerinin yapıldı̆̆ı sırada yeniden gündeme getirilecekti. Şubat 1924'de Şükrü Saraçoğlu, yaptığı bir konuşmada halkın okuma yazma oranının \%2 civarında olduğunu, bunun sorumlusunun da Arap harfleri olduğunu söylemişti. ${ }^{11}$

1926 yılında Latin harflerine geçileceğine dair çıkan söylentiler üzerine Şükrü Kaya bir açıklama yaparak Latin harflerinin kabulüyle ilgili hükümetçe kabul edilmiş bir

\footnotetext{
6 Durmuş Yalçın vd., Türkiye Cumhuriyeti Tarihi II, 9. Bask1, Ankara, Atatürk Araştırma Merkezi, 2012, s.110.

7 Cemal Avc1, "Harf İnk1labı ve Millet Mektepleri", Mediterranean Journal of Humanities, Akdeniz İnsani Bilimler Dergisi, Akdeniz Üniversitesi, III/1, 2013, s.45.

8 Cemal Avc1, "Harf İnkılabı ve Millet Mektepleri", s.45.

9 Falih Rıfkı Atay, Çankaya, İstanbul, Pozitif Yayınları, s. 507.

10 Falih Rıfkı Atay, Çankaya..., s.505.

11 Seda Bayındır Uluskan, Atatürk'ün Sosyal..., s.192.
} 
karar olmadığını ifade etti. Bu söylentinin çıkmasının bir nedeni de pullar üzerinde yer alan Latin harfleri kullanılan birkaç kelimeydi. ${ }^{12}$

1927 sonlarına doğru Latin yazısını Türkçeye uygulama denemeleri başladı. Bu denemelerin, Aralık 1927 ile Mayıs 1928 arasında çıkan bir dizi yazıyla en kapsamlısını yapan ve Atatürk'ün bu konudaki görüşünü yansıttığı anlaşılan Ahmet Cevat (Emre), Ayyaz İshakî'nin tersine yazı değiştirme sorununun bir ulusal hars (kültür) sorunu değil, bir uygarlik sorunu olduğunu savundu. ${ }^{13}$

23 Mayıs 1928 tarihinde Bakanlar Kurulu kararı ile Latin harfleriyle yeni Türk alfabesini hazırlamakla görevlendirilen bir heyet oluşturuldu. $\mathrm{Bu}$ dil encümeninde; Falih Rıfkı Atay, Yakup Kadri Karaosmanoğlu, Ruşen Eşref Ünaydın, Ahmet Cevat Emre, Ragıp Hulusi Özdem, Fazıl Ahmet Aykaç, İbrahim Grantay, Mehmet Emin Erişirgil, İhsan Sungu görev almışlardı. ${ }^{14}$

9/10 Ağustos 1928'de Sarayburnu'nda yaptığ1 konuşmada Mustafa Kemal Paşa “... Yeni Türk harflerini çabuk öğrenmelidir. Vatandaşa, kadına, erkeğe, hamala, sandalcıya ögretiniz... " diyerek hem halkı aydınlatmış hem de Harf İnkılabını başlatmıştı. ${ }^{15}$

Mustafa Kemal Paşa, alfabe seferberliğini, halka duyurmak ve tanıtmak amaciyla yurt gezilerine de çıkmıştı. Gittiği yerlerde yazı tahtasının başına geçerek yeni Türk alfabesini tanıtıyor, yeni yazıyı öğrenenleri sınavdan geçiriyor ve toplumdaki tepkiyi saptamaya çalışıyordu. 23 Ağustos'ta Tekirdağ'da bu konudaki ilk dersini vermişti. Tekirdağ’da 23 A ğustos 1928 tarihinde başladığı Bursa, Çanakkale, Maydos (Eceabat), Gelibolu, Sinop, Samsun, Turhal, Tokat, Sivas, Şarkışla ve Kayseri'den oluşan Gezi Programını 20 Eylül 1928 tarihinde tamamlayarak Ankara’ya dönmüştü. ${ }^{16}$ Başbakan ve diğer önemli isimler de onu izlediler ve kısa zamanda bütün ülke, halka yeni yazıyı okuyup yazmayı öğreten, kara tahta ve sehpalarla donatılmış bütün aydınlarıyla bir ders odasina döndü. ${ }^{17}$

Mustafa Kemal Paşa 1 Kasım 1928 tarihli meclisi açış konuşmasında Latin harflerine geçiş nedenini Latin esasına dayalı Türk alfabesinin Türk diline daha uygun

12 "Latin Hurufat1", Cumhuriyet, 11 Mart 1926, s.3.

13 Niyazi Berkes, Türkiye'de Çă̆daşlaşma...,s.549.

14 Seda Bayındır Uluskan, Atatürk'ün Sosyal...,s.194.

15 Cemal Avc1, "Harf İnkılabı ve Millet Mektepleri”, s.49.

16 Fahri Kılıç, Yeni Türk Alfabesinin...,s.81; Şerafettin Turan, Türk Devrim Tarihi 3, Kitap (Birinci Bölüm) Yeni Türkiye'nin Oluşumu (1923-1938), 3. Bask1, Ankara, Bilgi Yayınevi, 2013, s.207.

17 Bernard Lewis, Modern Türkiye'nin Doğuşu, Çev. Metin Kıratlı, 7. Baskı, Ankara, Türk Tarih Kurumu Yayınları, 1998, s.277. 
olduğunu belirterek, "kolay bir okuma yazma anahtarl” olarak tanımladi. ${ }^{18}$ Ardından İsmet Paşa'da yeni alfabenin kolaylığına vurgu yaparak yeni alfabenin halka öğretilmesi için Millet Mektepleri Teşkilatının kurulacağını duyurdu.

\section{Millet Mektepleri Teşkilatı}

İsmet Paşa 1 Kasım 1928 tarihinde yeni alfabe ile ilgili kanun görüşmeleri sırasında yaptığı konuşmasında Harf İnkılabını “milleti cehaletten kurtarma teşebbüsü” olarak özetledikten sonra, inkılabın başarılı olacağına dair inancının ilk nedeninin halktaki istek, ikincisinin ise yeni harfleri öğrenmenin kolaylığı olduğunu ifade etti. Millet Mekteplerini ise bu kolaylıktan hakkıyla istifade edebilmek ve birkaç sene içinde gözle görülür sonuçlar alabilmek için hükümetin çabalarından biri olarak sundu. ${ }^{19}$

8 Kasım 1928 tarihindeki meclis konuşmasında ise Millet Mekteplerinden bahsederken, sistemin kolaylığını öne çıkarmıştı. Millet Mektepleriyle yeni Türk harfleri tüm vatandaşlara kapılarının önünde, işlerinin başında öğretilebilecekti. Millet Mektepleri köy şehir demeden tüm yurdu kaplayacak, vatandaşların en müsait zamanlarında ve yakınlarında iki ya da dört aylık kurslar açılacak; şehirde ve köyde mekteplere, belirli toplanma yerlerine vakitleri müsait olmayan vatandaşlar için seyyar muallim teşkilatı yapılacak; devletin en büyüğünden en küçüğüne kadar bütün memurları Millet Mektepleri teşkilatında ihtiyaca göre çalışacaklardı. Gazi Mustafa Kemal Paşa da Millet Mektepleri teşkilatının Genel Başkanlığını ve Başöğretmenliğini kabul etmişti. ${ }^{20}$

Millet Mekteplerinde ilköğretim çağını geçiren vatandaşlara eğitim verilecekti. Mustafa Necati Bey'den sonra geçici olarak Maarif Vekilliği görevini üstlenen İsmet Paşa'nın öğretmenlere gönderdiği genelgede bu husus vurgulanarak "Türk Harfleri Usul-i Tedrisi” kitapçığının iyi okunması, Millet Mekteplerine devam eden halkın yetişkin olduğunun unutulmaması ve ona göre davranılması, yeni yazıyı öğretmenin yanı sıra vatandaşlara temiz, düzenli yaşama şeklinin de gösterilmesi istenmişti. ${ }^{21}$

Millet Mektepleri Teşkilatının işleyişini ve bağlı olduğu kuralları ortaya koymak için Millet Mektepleri Talimatnamesi hazırlanmış ve bu 52 maddelik talimatname Bakanlar Kurulunun 8 Kasım 1928 tarihli toplantısında kabul edilerek, 24 Kasım 1928 tarihinde

18 TBMM Zabıt Ceridesi, D.III, İ.S. II, C.V, (1.11.1928), s.4.

19 TBMM Zabit Ceridesi, D.III, İ.S. I, Cilt: V, (1 Kasım 1928), s.7-8.

20 TBMM Zabıt Ceridesi, D.III, İ.S.III, Cilt:V, (8 Kasım 1928), s.26.

21 Yasemin Kıroğlu, "Harf İnkılâbı'nın Atatürk Devrimlerinin Yayılmasına Etkisi”, Yayınlanmamış Yüksek Lisans Tezi, İstanbul, Marmara Üniversitesi Türkiyat Araştırmaları Enstitüsü Atatürk İlkeleri ve İnkılap Tarihi Anabilim Dalı, 2008, s.26-27. 
Resmî Gazetede yayınlanmıştı. ${ }^{22} 1928$ talimatnamesi ilk dönemin ardından edinilen tecrübeye göre tadil edilecek ve 56 maddelik yeni bir talimatname oluşturulacaktı. ${ }^{23}$

1928 talimatnamesine göre Millet Mektepleri teşkilatı A ve B dershaneleri olarak iki sınıftan oluşacaktı ve bu dershaneler sabit ve seyyar şekillerde eğitim imkânı sunacaktı. A dershaneleri tahsil çağını geçirmiş olup ne Arap ve ne de Türk harflerini bilmeyen vatandaşların okuma yazma öğrenmeleri için dört aylık bir dönemi kapsayacaktı. B dershaneleri ise eski Arap harfleriyle okuyup yazma bilen ama yeni Türk harflerini bilmeyen vatandaşlar için iki aylık bir dönemden ibaretti. ${ }^{24}$ Ancak 1929 Talimatnamesi ile Millet Mekteplerine gelen vatandaşlara bazı temel pratik bilgiler de verilmek istendiği için B sınıfları A sınıflarını bitirenlerin girebilecekleri bir üst sınıfa dönüştürüldü. ${ }^{25}$

1929 Talimatnamesiyle sabit ve seyyar A dershanelerinde okuma yazma bilmeyenlere veya Arap harfleriyle okuma yazma biliyor olup, yeni alfabeyi bilmeyenlere yeni harfler öğretilecekken (madde 4), sabit ve seyyar B dershanelerinde A dershanelerini bitirip, okuma yazma öğrenenlere, günlük hayatta ihtiyaçları olacak temel bilgi ve beceriler kazandırılması ile vatandaşlık tanımının gerektirdiği bilgilerle donatılmaları amac1yla eğitim verilecekti. (m.5). ${ }^{26}$

Millet Mekteplerinin kuruluş amacı 1928 talimatnamesinde "yeni Türk harflerinin kısa bir zamanda ve kolay surette her ferde okuyup yazabilmek imkânını bahşeden mahiyetinden Türk Milletini azami surette istifade ettirmek ve büyük halk kitlelerini süratle okuryazar bir hale getirmek maksadıyla millet mektebi teşkilatı yapılmıştır" şeklinde belirtilmişti. ${ }^{27} 1929$ talimatnamesinin birinci maddesinde Millet Mekteplerine yeni bir görev yüklenerek amaç "Türkiye halkını okuyup yazmaya muktedir bir hale getirmek ve ona hayat ve maişetinin gerektirdiği ana bilgileri kazandırmak maksadıyla Millet Mektepleri Teşkilatı vücuda getirilmiştir" şeklinde tanımlanırken sabit ve seyyar (B) dershanelerinin hedefi açıklanırken "vatandaşlık tanımlarının gerektirdiği ana bilgilerle donatmak" ifadesine yer verilmişti. ${ }^{28}$

22 T.C. Resmî Gazete, Say1:1048, 24 Kasım 1928, s.6101.

23 T.C. Resmî Gazete, Sayı:1321, 16 Ekim 1929, s.8395.

24 T.C. Resmî Gazete, Sayı:1048, 24 Kasım 1928.

25 Şerafettin Turan, Türk Devrim Tarihi 3..., s.211.

26 T.C. Resmî Gazete, Say1:1321, 7 Ekim 1929, s.8396.

27 T.C. Resmî Gazete, Say1:1048, 24 Kasim 1928, s.6101.

28 T.C. Resmî Gazete, Say1:1321, 16 Ekim 1929, s.8396. 
Böylece Millet Mektepleri halkın yeni alfabeyi kolayca öğrenmesi ve okuryazar oranının yükseltilmesi için kurulmuştu ve halka ihtiyacı olduğu düşünülen temel bilgilerin kazandırılması amacıyla da faaliyetine devam etmişti.

Millet Mekteplerinin tanıtılmasına ilk günden itibaren büyük önem verilmiş ve bu faaliyetlerin neler olabileceği ile ilgili bilgiler Millet Mektepleri Talimatnamesinde ayrı bir başlık altında detaylıca belirtilmişti. İlk talimatnameye göre Millet Mektepleri İdare Heyeti tarafından halkın yeni harflere karşı ilgisini arttırmak ve cazip hale getirmek için propaganda heyetleri oluşturulacaktı. Bu heyetler, sinema ve tiyatrolarda matineler arasında okuyup yazmanın faydalarına ait uygun propaganda devreleri düzenlemek; kahvehane ve gazino gibi halka açık yerlerde, kasaba ve köylerde panayır, pazar, güreş, koşu, sergi gibi geniş halk kitlelerini çeken yerlerde konferanslar vermek, tedris levhaları asmak, ilgi çekici gösteriler tertip etmek; Mecmua, gazete, risale gibi yayınlar hazırlamak, şehir ve köylerde halkın ilgisini çeken konular duvar gazeteleri ve tabelalar yazdırmak ve astırmak; imkân bulunan yerlerde radyo hitabeleri düzenlemek ve caddelere, meydanlara yerleştirilecek hoparlörlerle halkı aydınlatmak ile görevliydiler. Maddenin sonunda propaganda faaliyetleri ve araçlarının ancak gerektiği kadar kullanıldığında faydalı olacağı bu yüzden de aşırıya kaçmamak ve halkı taciz etmemek gerektiği notu düşülmüştü (m.44). ${ }^{29}$

1929 talimatnamesinde ise 48. maddede bu konuya ver verilmişti. 28. ve 29. maddelerde ise açılış günü hazırlıkları hakkındaki detaylardan bahsedilmekteydi. Millet Mekteplerinde öğrenime başlanmadan birkaç gün evvel idare heyeti tarafindan gazete ve dergilerde yayın yapılarak, bildiriler yayınlanarak, duyurular yapılarak, davul, etiket ve benzeri her çeşit yayın ve bildiri vasıtalarından yararlanılarak öğretime başlanacağı bu müesseselere devam etmenin bireylere ve topluma kazandıracakları vatandaşlara duyurulacaktı (m.28). Açılış günü olan 1 Kasım'da köy, şehir ve kasabalar bayraklarla donatılacak, mekteplerde orkestralarla konserler düzenlenecek, halkı büyük meydanlarda, toplantıya müsait yerlerde toplayarak nutuklar gerçekleştirilerek açılış günü kutlanacaktır (m.29). ${ }^{30}$ Yine talimatnameye göre ilk derste öğretmen Millet Mektebinin gayesi, okuyup yazmanın gerekliliği ve faydası hakkında en fazla on beş dakika sürecek bir konuşma yaptıktan sonra derse başlayacaktı. ${ }^{31}$

29 T.C. Resmî Gazete, Say1:1048, 24 Kasim 1928, s.6107.

30 T.C. Resmî Gazete, Say1:1321, 16 Ekim 1929, s.8399.

31 T.C. Resmî Gazete, Say1:1321, 16 Ekim 1929, s.8399. 
Millet Mektepleri, 1 Ocak 1929 tarihinden itibaren planlandığ 1 gibi görkemli açılışlara sahne olmuştu. İstanbul'da ilk tören öğleden sonra Taksim'de yapıldı. Saat 14'te çeşitli okullara bağlı izciler Taksim meydanında toplanmış bulunuyorlardı. Darüleytam talebelerinin ve şehir bandosunun katılımından sonra resmi geçit başladı. En önde şehir bandosu, sonra darüleytam talebeleri ve onları takiben de İstanbul ve Galatasaray liseleri, Ameli hayat izcileri yürüyüş yaptılar. Taksim abidesinin selamlanmasından sonra alay geniş bir halk kitlesi ile çevrili bir halde İstiklal Caddesi, tepebaşı yolundan Karaköy'e indi ve orada mektepler ayrıldılar. Gece yapılan merasim de oldukça parlakt1. Bilhassa Galatasaray Lisesiyle Beşinci ilk mektepte yapılan merasim mükemmeldi. ${ }^{32}$

Açılış günü mektepler süslenmişti ve pek çok mektebin dış cephesi elektrik tesisatıyla donatılmıştı. Kadıköy'de her mektepte akşam saat 5'ten 8'e kadar müsamereler düzenlenmesi planlanmıştı. Bu müsamerelere hükümetin önde gelenleri, milletvekilleri ve çocukların velileri davet edilmişti. Üsküdar Askeri Fırka Kumandanlığı da törene bir bando ekibi gönderecekti. Resmi açılışı takiben öğretmenler, örnek bir ders vereceklerdi. Elektrik alamayan mekteplerin aydınlatma vasıtaları da Üsküdar aza heyeti tarafından temin edilmişti. ${ }^{33}$ Açılış gününün tek üzücü hadisesi Maarif Vekili Necati Bey’in vefatı olmuştu. ${ }^{34}$

Millet Mektepleri Açılış Merasimi programı şu şekilde planlanmıştı:

1. İlk mektepler tamamen donatılacakt1.

2. Mektepler açılırken vali, maarif erkânı ve müdür ile muallimler tarafından Türk harfleri hakkında konuşmalar yapılacaktı.

3. Harfler marşı ve İstiklal marşı söylenecekti.

4. Mektep talebeleri tarafından temsiller verilecek, bazı mekteplerde bandolar bulunacak şenlikler düzenlenecekti. ${ }^{35}$

Açılış günü heyecanı gazete sütunlarında şu şekilde yer bulmuştur: Açılış akşamı saat altıdan sonra yalnız İstanbul'da 60 bini aşkın kişi “mekteplere giderek, yeni derse başlayan çocuklar gibi, ellerinde kitap sıralara oturdular, okumaya başladılar. Birçok kadınlar kucaklarında çocukları ile beraber mekteplere giriyorlar ve beyaz sakallı ihtiyarlar ellerinde defter dershanelerin en ön sıralarını işgal ediyorlardı. Bu münasebetle

32 “Halk Mektepleri”, İkdam, nr. 11386, 2 Ocak 1929, s.1.

33 "Bugün Maarif Bayramı var", Cumhuriyet, 1 Ocak 1929, s.1.

34 "Millet Mektepleri Dün Gece Açıldı", Cumhuriyet, 2 Ocak 1929, s.4.

35 “Okuma yazma seferberliği bugün başlıyor; Büyük tezahüratla Millet Mektepleri akşama açılacaktır”, Milliyet, 1 Ocak 1929, s.1. 
bütün mekteplerde merasim yapıldı. Nutuklar irad edildi. Nümayişler yapıldl, şenlikler icra edildi. Bütün hükümet erkân,, Vali, Polis müdür, maarif emini, Maarif müdürü, Maarif erkânı mekteplerde yapılan merasimde hazır bulundular. ${ }^{\prime 36}$

Vali Muhittin Bey Unkapanı, Fatih, Cibali, Kasımpaşa ve diğer semtlerde açılan mektepleri teftiş ve ziyaret ettiğinde bütün bu mekteplerde kadınların daha büyük bir heyecanla sıralarda ders okuduklarını görmüştür. ${ }^{37}$ Vali Muhittin Bey Maarif Müdürü Haydar Bey ile sırasıyla Galatasaray'da, Nişantaşı 12nci, Beyazıt 5'inci ve 6'ncı, Unkapanı 40ıncı mekteplerde açılan Millet Mekteplerinin açılış merasiminde bulunduktan sonra Eyüp 36ıncı ilk mektebe gitmişti. Bu son mektepte halk dağılmıştı. Vali beyin ziyareti üzerine tekrar toplanmış, kendilerine Harf İnkılabının önemi hakkında izahat verilmişti. ${ }^{38}$ Milliyet Gazetesi, Gelibolu, Denizli, Muğla, Konya, İnegöl, Adana, Kastamonu, Kırşehir, Samsun, Bolu, Giresun, Çankırı, Gerede muhabirlerinden de parlak açılışlar hakkında telgraflar aldığını belirtmekteydi. ${ }^{39}$

Gazete haberlerine göre, açılışın sadece dört gün sonrasında Millet Mekteplerinde oturacak yer kalmamıştı. Halk dershanelere adeta hücum etmişti ve 50 kişinin alınması gereken dershaneye 100 kişi kabul edilmiş olmasına rağmen talep karşılanamamıştı. Maarif idaresi civardaki diğer bazı okulları Millet Mektepleri haline getirmeye karar vermişti. Bununla birlikte bunların da ihtiyaca kâfi gelmediği anlaşılarak Cemiyeti Umumiye-i Belediye salonunun da millet mektebi dershanesine dönüştürülmesi kararı alınmıştı. Üsküdar, Kadıköy, Boğaz, Beyoğlu gibi muhtelif yerlerde açılan dershaneler de yetersiz kalmıştı. Bu yoğun talepten dolayı bu eğitim devresine dahil olmayanlar hakkında kanuni işlem yapılmamasına karar verilmişti. Sınıfların doluluğu nedeniyle derslere katılamayanlar hakkında bir liste hazırlanacaktı ${ }^{40} \mathrm{Bu}$ istisnai durum dışındaki devamsızlıklarda ise, derslere devam etmeyenlerin isimleri polis merkezleri tarafindan mahalle ihtiyar heyetlerine bildirilmiş olup bunlar hakkında kanuni takibata başlanılacaktı. ${ }^{41}$ Devam mecburiyeti olduğu için, kayıt olmayanlar veya kayıt olup da devam etmeyenlerden 5 liradan 60 liraya kadar nakdi ceza alınacaktır. 1931 senesinden itibaren de Millet Mektepleri vesikası olmayanlar hiçbir işe kabul edilmeyeceklerdi. ${ }^{42}$

\footnotetext{
36 "Halk Mektepleri”, İkdam, nr.11386, 2 Ocak 1929, s.1.

37 "Millet Mektepleri", İkdam, nr.11387, 3 Ocak 1929, s.2.

38 "Herkes Okuyor", Son Saat, nr.1363, 3 Ocak 1929, s.1.

39 "Her tarafta Millet Mektepleri Açılmıştır", Milliyet, nr.1040, 3 Ocak 1929, s.2.

40 “Mektep yetişmiyor!”, İkdam, nr.11390, 6 Ocak 1929, s.1.

41 "Millet Mekteplerinde İmtihan ve devamsızlar", Son Saat, nr.14201 Mart 1929, s.4.

42 “Cehaletle Mücadele başladı”, İkdam, nr.11680, 2 Kasım 1929, s.5.
} 
Millet Mektepleri talimatnamelerine göre kadınlara ve erkeklere ayrı ayrı veya karışık sınıflar açılabilmektedir fakat uygulamada genelde ayrı sınıflar açılmıştı. Örneğin, ikinci sene İstanbul'da pazartesi-perşembe günü yalnız kadınlara ders verilecek, diğer günler de yalnız geceleri herkese mahsus dersler verilecektir. Bu derslere kadınlar da katılacaktır. ${ }^{43} \mathrm{Bu}$ arada dershanelerde çocuklarını emzirmekte olan kadınlar ikinci devreye bırakılacak, çocukları iki yaşından yukarı olan kadınlar için de bazı dershaneler açılacak, ders esnasında çocuklara ayrı odalarda hademeler bakacaktı. ${ }^{44}$

İkinci seneye ait Millet Mektepleri faaliyetine de 1929 Kasım ayı başında başlanarak Şubat 1930 sonuna kadar devam edilmesi planlanmıştı. Yeni ders senesinde özellikle hiç okuyup yazma bilmeyenlerin yetiştirilmesi amaçlanmıştı. Kasabaların bütün ilk mekteplerinde ve mektebi bulunan köylerin hepsinde Millet Mektepleri açılacaktı. ${ }^{45}$ Millet Mekteplerinin yeni senede daha iyi neticeler vermesi için bir hafta öncesinden maarifte ve İstanbul vilayet idaresinde hazırlıklara başlandı ve bekçiler de halkı dershanelere davet ettiler. ${ }^{46}$

İkinci yıl da açılışlar için büyük hazırlıklar yapılmıştı. Açılış ve kayıt kabul tarihlerinin davullarla halka ilan edilmesi planland1. Ekim sonu itibariyle İstanbul' da 700 dershane hazırland1. Millet Mekteplerinin açılacağı gün gerek şehir gerek dershaneler baştanbaşa donatılacak ve vali, maarif emini, maarif müdürü gibi yönetim kadrosu da açılış merasiminde hazır bulunacakt $1{ }^{47}$ Açılışlar yine halktan büyük ilgi görmüş hatta birçok mektepte temsiller, halk müsamere salonuna sığmadığı için tekrar edilmişti. ${ }^{48}$ İstanbul dışındaki illerde de Millet Mektepleri açılışı coşkulu olmuştu. Diyarbakır, Manisa, Ankara, Kırklareli, İzmir, Kütahya gibi illerde de mektepler süslenmiş, askeri kumandanlar veya şehrin önde gelenleri açılışlara katılmıştı. ${ }^{49}$

Halk fırkası da bütün teşkilatına bir tamim göndererek Millet Mektepleri için harekete geçmelerini tavsiye etti. ${ }^{50}$ Tamimde, Millet Mektepleriyle hedeflenen kutsal amacın gerçekleştirilebilmesi için firkaya önemli görevler düştügüüü, cehalet denilen en kötü düşmana karşı fırkanın adeta bir askeri şube gibi sorumlu olduğu hatırlatılmıştı. Bütün

43 "Bari bu sene ciddi tutulsa", İkdam, nr.11675, 26 Ekim 1929, s.2.

44 "Kadınların hücumu”, Milliyet, nr.10414, Ocak 1929, s.1.

45 "Maarif Vekâleti bir vergi tesisini istiyor", Cumhuriyet, nr.1805, 17 May1s 1929, s.2.

46 “Cehaletle Mücadele başladı”, İkdam, nr.11680, 2 Kasım 1929, s.5.

47 "İstanbul'da Millet Mektepleri için 700 dershane açılmıştır. Mektepler 1 teşrinisani akşamı açılacaktır”, İkdam, nr.11677, 28 Ekim 1929, s.1.

48 "Millet Mektepleri dün merasimle açıldı", Cumhuriyet, nr.2331, 2 Kasım 1930, s.2.

49 “Millet Mektepleri açıldı”, Cumhuriyet, nr.1970, 2 Kasım 1929, s.1; "Diyarbekirde samimi merasimle açıldı”, nr.1972, 4 Kasim 1929, s.3.

50 “İstanbul'da Millet Mektepleri için 700 dershane açılmıştır. Mektepler 1 teşrinisani akşamı açılacaktır”, İkdam, nr.11677, 28 Ekim 1929, s.1. 
fırka üyelerinin devlet memurlarına elden geldiğince yardım etmekle beraber inkılabın kesin zaferini sağlamak önemli olan bu büyük girişimde gayet istekli ve rekabetçi bir şekilde yer almaları istenmekteydi. Halkın talimatnameye uygun olarak Millet Mekteplerine devamı ve açılış gününde yerini almasının sağlanması için ihtiyar heyetleri ile ortak hareket edilmesi istenmekteydi. ${ }^{51}$

Üçüncü sene de yine Vilayetlere gönderilen bir tamimle konuya dikkat çekilmişti. 1930 Ekim'inde Maarif vekili bütün vilayetlere bir tamim göndererek 1 Kasım'da Millet Mekteplerinin açılacağını bildirmiş ve önem verilecek noktaları belirtmişti. Buna göre ilk olarak1929 yılında okumaya başlayan vatandaşların okuma becerilerini arttırmak ve kendi düzeylerinde olan yayınları okuyup anlayacak hale getirip, onlara faydalı yayınlar okuma merak1 aşılamak isteniyordu. İkinci olarak ise henüz yeni alfabeyi öğrenmemiş olan vatandaşların bir an evvel cehaletten kurtarılmasına çalışmak amaçlanmıştı. Aynı tamimde bir önceki sene vilayet raporlarındaki tavsiyelere istinaden değiştirilmek üzere olan talimatnamenin muaddel maddelerinin de kısa sürede tebliğ edileceği de bildiriliyordu. ${ }^{52}$

Millet Mektepleri bütçesi her vilayet ve kazada millet mektebi idare heyeti tarafindan hazırlanarak ve Maarif Vekâletine tasdik ettirilecekti. Bütçenin kaynakları ise şunlardı:

A) Hususi bütçelerden tefrik ve nakil olunacak miktar,

B) Mahalli ticaret ve ziraat odalarından tahsis edilecek muavenet,

C) Mahalli belediyelerden yapılacak muavenet,

D) Hususi bağışlar,

E) «Gazi hitabesi» plağından elde edilecek gelirin tamamı. ${ }^{53}$

Vilayet bütçelerinin Millet Mektepleri için tahsisat ayırabilmesi için 10 Kasım 1928’de 1354 sayılı “1928 senei maliyesi Maarif Vekâleti bütçesine tahsisatı fevkalade itasına ve muhtelif devaîr bütçelerine mevzu tahsisattan bazllarının imhasına dair Kanun” çıkartılmıştır. Kanunun ilk maddesinde "1928 senei maliyesi Maarif Vekâleti bütçesinde (yeni Türk harflerinin istilzam eylediği masraf) namile yeniden açılan 718 inci fasla 400000 lira tahsisatı fevkalade olarak vazolunmuştur." denmektedir. ${ }^{54}$

51 "Millet Mektepleri teşrinisanide aç1llyor", Cumhuriyet, nr.1966, 28 Ekim 1929, s.1; "İstanbul'da Millet Mektepleri için 700 dershane açılmıştır. Mektepler 1 teşrinisani akşamı açılacaktır”, İkdam, nr.11677, 28 Ekim 1929, s.1.

52 "Millet Mektepleri hazırlığı başladı", Cumhuriyet, nr.2317, 18 Ekim 1930, s.3.

53 T.C. Resmî Gazete, Say1:1048, 24 Kasim 1928, s.6105-6106

54 Kanunlar Dergisi, Cilt:7, s.3. 
Ayrıca 26 Aralık 1928 tarihli bakanlar kurulu toplantısında Millet Mektepleri için özel idarelerin maarif kısmı için ayrılan gelirler dışında belirli bazı işler için ayrılan paradan da harcama yapılabilmesi kabul edildi. ${ }^{55}$ Millet Mektepleri bütçesi için ek tahsisatlar ayrılacaktı. Örneğin henüz 20 Ocak’ta İstanbul Valisi Muhittin Bey’e yeniden millet mektebi açmak için ek (munzam) tahsisattan 130 bin lira verilecekti. ${ }^{56}$ Dört gün sonrasında İstanbul Vilayetine heyet-i vekilenin yeni bir kararnamesi tebliğ edilecekti. $\mathrm{Bu}$ kararnameye göre gerektiği takdirde maarif varidatından başka bütçelere ait gelirlerden de harcama yapılabilecekti. İlk adımda bu harcamaların bir kısmıyla kadınlara özel 100 dershane açılmasına karar verilmişti. ${ }^{57}$ Millet Mektepleri için özel idarelerin maarif kısmı bütçesi dışında, kanunen belirli başka iş ve cihetlere ayrılmış olan tahsisattan da harcama yapılabilmesi İcra Vekiller Heyetinin 26 Aralık 1928 tarihli toplantısında kabul edilmişti. ${ }^{58}$ Şubat ayı sonunda, şehremaneti de mekteplere harcanmak üzere 10 bin lira daha ayırmıştır. Bu para ile ihtiyaç görülen bazı semtlerde yeniden mektepler açılacaktı. Diğer taraftan Haziran'a kadar Avrupa'ya talebe gönderilmeyeceği haberi yer almaktadır. Avrupa'ya gidecek talebeye ait tahsisat da Millet Mekteplerine harcanacaktı. Sadece şubat sonunda Adliye Vekâleti adına Avrupa'ya hukuk eğitimi almak üzere beş erkek talebe gönderilmişti. ${ }^{59}$

Ancak ilerleyen dönemde Millet Mekteplerine ayrılacak bütçe konusunda bazı sorunlar yaşanacaktı ve bu durum Millet Mekteplerinin başarısını etkileyen nedenlerden biri olacaktı.

Millet Mektepleri bütçeleri Vilayet İdare Heyetlerince oluşturulmaktayd1. Bir bölgede açılacak dershanelerin türünü tayin ve her türden ne kadar dershanenin nerelerde açılacağını tespit etmek hakkı ilgili bölgenin millet mektepleri idare heyetine aitti (m.25). Millet mekteplerinin maarif müdürü ve ilk tedrisat müfettişleri tarafından teftişini mümkün k1lmak üzere her sene vilayet maarif bütçesinin hususi faslına kâfi miktarda harcırah ayrılacaktı (m.23). Millet Mekteplerinde görev alan, öğretmen, başöğretmen, kaza maarif memurları, ilköğretim müfettişleri ve maarif müdürleri hizmetlerine karşılık belirlenen ücreti alacakt1. ${ }^{60}$

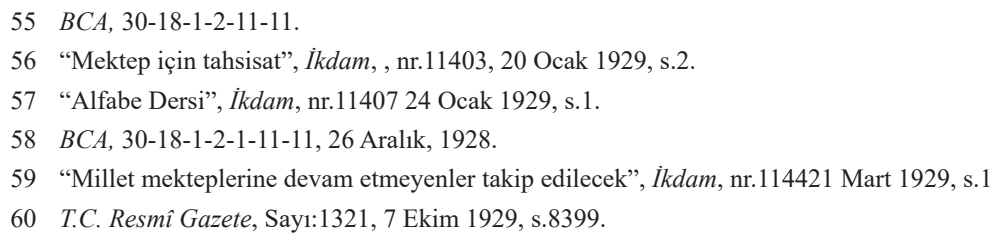


İlk sorun, Millet Mekteplerinde ders veren üst yönetim kadrosuna verilecek ücret konusunda olmuştu. Şöyle ki Millet Mektepleri talimatnamesi ile 1452 sayılı kanunun çelişkili olması nedeniyle Millet Mekteplerinde görev yapan müfettiş ve öğretmenlere ücret ödenmesi konusunda maarif ve maliye vekâletleri arasında bir fikir ayrılığg yaşanmıştı.

1452 sayılı "Devlet memurları maaşatının tevhit ve teadülüne dair kanun"un 15. Maddesinde, "Ihtisas ve komisyon ücreti ve makam tahsisatı ve tahsisatı maktua ve hakkı huzur namlarile memurlara ayrıca umumî ve hususi bütçelerden hiçbir meblăg verilmez. Ancak kanunun tahmil etmediği munzam bir vazifeye veya ihtisas dolaylsiyle tesis olunacak komisyonlara memur edilenlere muayyen çalışma saatleri haricindeki mesailerine mukabil İcra Vekilleri Heyetince takdir olunacak bir ücret verilebilir" denmektedir. ${ }^{61}$ (Kabul Tarihi: 24/05/1929)

Maarif Vekâleti evvelki senelerde verilen ve küçük bir tutar olan bu ücretlerin 1930 senesinde verilmemesinin, bu teşkilatın dağılması tehlikesini doğurduğunu ve bazı yerlerde ücretlerin verilmemesi yüzünden şimdiden kayıtsızlığın başladığını ifade etmekteydi. ${ }^{62}$

18 Aralık 1930 ile 1 Temmuz 1931 tarihleri arasında Eğitim ve Maliye Bakanlıkları ve son olarak Başbakanlık arasında devam eden bir dizi yazışmadan bu sorunu izlenebilmektedir. 1452 sayılı kanuna göre memurlara asli vazifeleri dışında bir vazife yüklenmediği takdirde çalışma saatleri dışındaki mesaileri için ek bir ücret ödenmeyecek olması, iki bakanlık arasındaki Millet Mektepleri için harcanan mesainin idari kadronun asli görevine dahil olup olmadığı konusunda bir fikir ayrılığına neden olmuştu. Maliye Bakanlığı, Maarif müdür ve memurlarıyla ilk tedrisat müfettişlerine millet mektepleri ile ilgili vazifelerinden ötürü ücret ödenemeyeceğini savunmaktaydı. ${ }^{63}$

Maliye Bakanlığına göre, Millet mektepleri faaliyetleri idari kadronun asli görevine dahildir ve bu fikri savunurken bazı tezler öne sürmektedir. Bunlardan ilki, Maarif müdür ve müfettişleri anayasa belirtilen mecburi ilköğretimi sağlamakla mükellef birer memurdurlar ve mesai saatleri dişında çalışsalar da asli görevleri dişında bir görev yapmış sayılmazlar. ${ }^{64}$ Ayrıca kendilerine bu ücretin ödenmesinin Teadül kanununun 15. maddesinin birinci fikrasıyla ilga edilmiş olan tahsisatı maktu ve makam ücretlerinin birer vesile ile ihya ve itasını temin etmek olacağını savunmaktadır. ${ }^{65}$

61 Kanunlar Dergisi, Cilt 7, s.551.

62 BCA, 30-18-1-2-21-46-19.

63 BCA, 30-18-1-2-21-46-19, 16 Şubat 1931.

$64 B C A, 30-18-1-2-21-46-19,7$ Şubat 1931.

$65 B C A, 30-18-1-2-21-46-19,16$ Şubat 1931. 
Maarif Vekâleti ise, halkı okutmak ve yetiştirme işinin yalnız masa başı ve kırtasi bir iş olmaktan ziyade teşvik, irşat, denetim ve daimî bir enerji ve faaliyet gerektiren bir iş olduğunu belirterek, bu memurların öğretmenlerden daha çok yorulduğunu, aynı zamanda bulundukları vilayetlerde "genel kâtip" olarak görev yaptıklarını, bütün yazışma ve istatistiki bilgilerden sorumlu olduklarını savunmaktaydı. Bu yüzden talimatnamenin 22nci maddesinde bu memurlara da ücret verileceği belirtilmişti. Bu ücretlerin verilmesi ilga edilmiş makam tahsisatı ve maktu ücretlerin yeniden ortaya çıkmasına sebebiyet vereceği iddiasına karşı ise, bir talimatname ile belirlenmiş oldukça düşük bir ücretin alınmasının hak olduğunu belirtmektedir. Ayrıca, yerine getirilmesi son derece zor olan vazife ve mesuliyetler için bu memurların haklarının verilmesi, Millet Mekteplerinin gelecek seneki faaliyeti üzerine de olumlu etki yapacaktı. ${ }^{66}$

Bütün bu yazışma sonrası, Millet Mektepleri Talimatnamesinin 22.inci maddesine uygun olarak ilgili memurlara ücret ödenmesi kabul edilmiştir. ${ }^{67}$

Millet Mektepleri, talimatnamelerde de belirtildiği gibi Vilayet yönetimindedirler ve Millet Mektepleri için vilayet bütçesinin eğitim kısmına tahsisat ayrılır. Bir il de kaç tane Millet Mektebi açılacağına Vilayet yöneticileri karar verecekti. Cumhuriyet gazetesinin haberine göre, 1934 y1lında Millet Mektepleri için İstanbul Vilayet bütçesine tahsisat konulmamıştı. Maarif idaresince 5000 liralık tahsisat gerekli görülmüş fakat bu talep kabul edilmemişti. Şehir Meclisi azasından Avni Bey, bu tahsisatın kabul edilmeme nedenini şöyle anlatmaktayd1: "Bu meselenin müzakeresi esnasında hazır bulunan Maarif Müdürü Haydar Bey, artık tahsisata lüzum kalmadığını, halkın mühim bir kısmının yeni harfleri öğrenmiş olduğunu, mütebakisi için Maarif idaresince tedbir alınacağını söylemişti. Mesul makamın bu mütalaasını nazari itibara alarak tahsisat koymaya lüzum görmedik. "'68

Böylece yeni sene şehir bütçesinde millet mektepleri için tahsisat ayrılmamıştı. Bu yüzden maarif müdürlüğü halkın ihtiyacını dikkate alarak, öğretmenlerin hamiyet ve fedakârlıklarına müracaat etmek suretiyle bu işi yürütmek niyetindeydi. Ekim ayında 60 dershane açılmasına karar verilmişti. Yeni harfleri öğrenenlerin imtihanlarına maarif müdürlüğünde devam edilerek her hafta 50 kadar müracaat sahibine diploma verilecekti. İstanbul bölgesinde verilen diploma miktarı 350 bini bulmuştu ve bu oranın \%25'ini kadınlar oluşturmaktaydı. ${ }^{69}$

66 BCA, 30-18-1-2-21-46-19, 16 Şubat 1931.

$67 B C A, 30-18-1-2-21-46-19,16$ Şubat 1931.

68 "Millet Mekteplerine niçin tahsisat verilmemiş?", Cumhuriyet, nr.3642, 27 Haziran 1934, s.2.

69 “İş muallimlerin hamiyetine kaldı", Cumhuriyet, nr.3639, 24 Haziran 1934, s.2. 


\section{Eğitim İçeriği}

Millet Mektepleri yeni alfabeyi halka öğretmek ve okuryazar oranını arttırmak amacıyla kurulmuştu. Bu okulları bitirenlerin okuma yazma becerilerini sürdürebilmelerine yardımcı olmak için de ilk dönemden itibaren haftalık bir dergi yayımlanmıştı. Halk Mecmuası isimli bu derginin ilk sayısı 11 Şubat 1929'da çıkmıştı. ${ }^{70}$ Bunun yanında Halk Mecmuası gibi, Maarif Vekâletinin Millet Mektepleri için bastırdığg özel alfabeler, yalın ve iri yazılı okuma kitapları da kurs öğrencilerine ücretsiz veriliyordu. ${ }^{71}$

Millet Mekteplerinde Talim ve Terbiye Heyeti tarafindan onaylanan kitaplar okutulacaktı. Millet Mekteplerini en iyi derece ile bitiren ilk üç kişiye içinde anayasa metninin yer aldığı bir kitapçık hediye edilecekti (madde 46). ${ }^{72}$ Kitabın başında "Millet mektebinden çıkan ... Efendiye tarafımdan hediyedir." Mustafa Kemal; yazacaktı. ${ }^{73}$ İçinde ayrıca, Atatürk'ün imzalı bir fotoğrafinın bulunduğu sayfa ve Gençliğe Hitabe olacaktı. ${ }^{74}$ Böyle bir hediye, vatandaşlık eğitiminin pekiştirilmesi bakımından anlamlı görülmektedir. ${ }^{75}$

İkinci dönemden itibaren vatandaşa bazı temel bilgiler kazandırılmak istenmesi sebebiyle eğitim içeriğine yeni dersler eklendi. Buna göre ikinci dönemden itibaren haftada toplam 6 saatlik ders verilecek A dershanelerinde dört saat Milli Talim ve Terbiye Heyeti tarafından belirlenen ve gösterilen şekilde alfabe, kıraat, imla ve yazı öğretilecek, iki saat ise matematiğin hayattaki gerekliliği ve faydası anlatılarak sayı sayma, yazma, toplama ve çıkarma işlemleri gösterilecekti. ${ }^{76}$

B dershanelerinde ise kıraat, imla, yazı ve tahrirle karışık olarak; hesap, sağlık ve yurt bilgisi dersi verilecekti. Yurt bilgisinde milli tarih ve coğrafya bilgisine özellikle önem verilecekti. B Dershanelerinde okutulan dersler ve haftalık süreleri şöyledir: Kıraat ve Tahrir 2 saat, Hesap ve Ölçüler 2 saat, Sağlık Bilgisi 1 saat, Yurt Bilgisi 1 saat. ${ }^{77}$ Derslerin öğretim şekli ve içerikleri talimatname kitapçığında gösterilmişti.

70 Şerafettin Turan, Türk Devrim Tarihi 3..., s.211-212.

71 İlhan Başgöz, Türkiye 'nin Eğitim Çıkmazı ve Atatürk, 3. Bask1, İstanbul, Pan Yayıncılık, 2004, s. 136

72 T.C. Resmî Gazete, , Say1:1048, 24 Kasım 1928 s.6107.

73 "Millet Mektepleri başmualliminin talebesine hediyesi”, Cumhuriyet, nr.1890, 13 Ağustos 1929, s.1.

74 Mücteba İlgürel, Millet Mektepleri (Doğumunun 100. Yılında Atatürk'e Armağan), Ayrı basım, İstanbul, İstanbul Üniversitesi Edebiyat Fakültesi Matbaas1, 1981, s.33-34.

75 Yahya Akyüz, Türk Eğitim Tarihi M.Ö. 1000 - M.S. 2015, Ankara, Pegem Akademi, 2015, s.405.

76 BCA, 490-1-0-0-1-3-12. (Millet Mektepleri Talimatnamesi ve Tatbikine Rehberlik Edecek Dahili Talimatnameler, 2. Bölüm, Millet Mektepleri Teşkilatında Maarif Memurlarının Vazifeleri)

77 BCA, 490-1-0-0-1-3-12. 
Kıraat dersinin amacı kolayca ve doğru okuma ile okuma sevgisi aşılamaktı (okumak zevkini almak) ${ }^{78} \mathrm{Bu}$ amaçları gerçekleştirmek için izlenecek yöntemler de belirtilmişti. Talebenin ilgi duyacağı parçalar okutulacak ve anlaşılması sağlanacaktı. Bir parça okunmadan evvel, gerektikçe, öğretmen parçanın konusu veya ana fikri hakkında talebelere bilgi verecekti. Okuma kitabı olarak seçilen kitaptan yararlanılacak olmakla birlikte ara sıra güzel halk şiirlerinden veya yeni şiirlerden seçmeler okutturulması gerekli görülmüştü. Öğretmenden okutulan parçaların halka zararlı fikirler vermeyecek parçalar olmasına dikkat etmesi, şiir ve estetik değeri olan parçalarda güzel kısımlarda talebenin dikkatini çekmesi beklenmekteydi. On beş günde bir gazete veya dergilerden uygun makalelerin ve fikraların okutturulması ve okutulacak yazıların halkı ilgilendiren ya da ilgilendirmesi gereken olaylara ait olması faydalı bulunmuştu. Polis vakalarına ve cinayetlere ait yazılar kesinlikle okutulmayacaktı. Okunan yazılar hakkında yapılacak tartışmalarla güzel konuşma ve okuma alışkanlığı kazandırılmasına çalışılması gerekli görülmüştü. ${ }^{79}$

Kompozisyon (tahrir) derslerinde talebelere aşamalı olarak, fikirlerini düzgün ve anlaş1lır şekilde yazabilmeyi öğretmek amaçlanmıştı. Mektup, tezkere telgraf, senet gibi hayatta daima ihtiyaç duyulan konuların seçilmesi faydalı görülmüş ve tahrir dersleri mektupların şekil kurallarını da içermektedir. Düzgün tarih atmak ve adres yazmak gibi. Talebeye yeri geldikçe imla ve gramer kaidelerinden bahsedilecek, sıkça yaptıkları imla, gramer ve harf dizim (nahiv) hataları düzeltilecekti. ${ }^{80}$

Dershanelerde bu ders için Sabri Cemil'in Kıraat kitabı okutulmaktaydı. Bu kitap, ahlaki, vatani ve milli esaslara göre seçilmiş parçaları içermekteydi. 128 sayfalık küçük bir kitap olan eser, şiirler, hikâyeler, destanlar ve bazı tarihi parçalarla yaşı ilerlemiş öğrencilerin ilgisini çekecek şekilde hazırlanmıştı. ${ }^{81}$

Hesap ve Ölçüler dersinin temel amacı gündelik hayatta daima rastlanan ve zihni hesapla her zaman halledilemeyen basit meselelerin çözümüne yarayacak genel esas ve kuralları öğretmek ve bunları kolay, doğru ve çabuk kullanma becerisi kazandırmaktı. ${ }^{82}$

Derste önce sayılar öğretilecek, talebe yeterince beceri kazandıktan sonra toplama işlemine geçilecekti. Derslere önce problem ve örneklerle başlanacak, bunlardan

\footnotetext{
$78 B C A, 490-1-0-0-1-3-12$.

$79 B C A, 490-1-0-0-1-3-12$.

80 BCA, 490-1-0-0-1-3-12.

81 Mücteba İlgürel, Millet Mektepleri..., s.28.

82 BCA, 490-1-0-0-1-3-12.
} 
kurallara varılacaktı. Talebenin en baştan itibaren hızlı ve doğru ilerlemesine çalışılacaktı. Sayılar öğretilirken ölçüler konusuna da girilecek, talebeye, toplama ve çıkarma işlemleri ayrı ayrı öğretildikten sonra her iki işlemin karışık olduğu problemler verilecekti. Ölçülerde uygulamanın faydalı olacağı belirtilmekteydi. Derslerde hayattan uzak birtakım konulara fazla yer verilmeden, dershanedeki çeşitli meslek erbabını en çok ilgilendirecek konuların seçilmesi gerekli görülmüştü. Çarpım tablosu ve kuralları da aşamalı olarak öğretilecek, bölmeye önce kesirsiz neticeler verecek problemlerle başlanacak, bir taraftan ölçüler de kullanılırken yavaş yavaş kesirli netice verecek problemlere geçilecekti. Derste öğretilecek ölçüler şunlardır: okka-dirhem; kilogram: metre-santimetre ve kilometre; arşın; lira-kuruş-para; kuruş-santim. Bunların dışında en çok kullanılan mahalli ölçüler de öğretilecekti. Metre ve arşın ile dershane dahilinde yüzölçümleri yaparak uzunlukların ölçülmesi iyice öğretilecek ve bundan kare ve dikdörtgen alanlara geçilecekti. Alan ölçüsünde dikdörtgenden daha ileriye gidilmeyecekti. ${ }^{83}$

Sağlık Bilgisi dersinin amaçları vücut, organlar ve görevleri hakkında temel fikirler vermek ile bireysel ve toplumsal sağlık esaslarını öğretmek ve alışkanlık kazandırmaktı. ${ }^{84}$

Derslerin olabildiğince talebeyle karşılıklı konuşma, sohbet şeklinde yapılması ve mümkün mertebe resim, levha, diyagram gibi araçlardan yararlanılması dersin amacına ulaşmasında faydalı görülmüştü. Sağlık bilgisi dersine konu olan içerik şöyleydi: ${ }^{85}$

İnsan bedeni, başlıca organlar ve görevleri (nefes alma, ciğerler; kan, dolaşım ve kalp; yemek ve hazım, ağız, dişler ve bağırsaklar). Hava, su, gıdalar hakkında sağlık tavsiyeleri. İçki ve zararları (İçkinin ferde, aileye, millete zararları: İçki az kullanan milletlerde umumi refah ve saadet; içki çok kullanan milletlerde sefalet). Ölümcül hastalıklar (Frengi, Verem, sıtma, belsoğukluğu; bunlardan korunma). Milletin sağlığı için herkes nelere dikkat etmeli: Sokakta, vapurda, tramvay ve otobüste tükürmenin zararları.

Giyinmenin sıhhi şartları. Çocuklara nasıl bakmalı ( kadınlar için )

Kır ve açık hava ve güneşin faydaları.

Bulaşık hastalıklardan çekinme; halkın bu hususta vazifeleri.

Kazalar; zehirlenmeler; Hayvan 1sırmaları; bunlarda ne yapılır? (Bunun için mümkün olan yerlerde hükümet doktoru tarafından uygulamalı bir iki ders verilmelidir.)

$83 B C A, 490-1-0-0-1-3-12$.

84 BCA, 490-1-0-0-1-3-12.

$85 B C A, 490-1-0-0-1-3-12$. 
$\mathrm{Bu}$ derste kullanılan Muhittin Celal Bey'in "Millet Mektepleri ile Halk Dershanelerine Mahsus Sağlık Bilgisi” kitabı temel sağlık bilgilerinin verildiği 16 bölümden oluşmaktadır. Konuların daha iyi anlaşılması için resimlere yer verilmiştir. Büyük puntolarla sade ve anlaşılır bir dil kullanılmıştır.

Bölüm başlıkları ve uzunlukları şöyledir ${ }^{86}$ :

1. Her işin başı sağlıktır. (s. 3-8)

2. Vücudun yapısı ve işi (s.9-14)

3. Hareket cihaz1 (s. 15-28) (Kemikler ve adalelerden bahsediliyor)

4. Hazım cihazı (s.29-35) (Sindirim sistemi)

5. Teneffüs cihazı (s.36-40) (Solunum sistemi)

6. Kan ve deveran cihaz1 (s.41-47) (Kalp ve damarlar)

7. Sinir cihazı ve duygular (s.48-59) (Beş duyu)

8. Hava, su, gida (s. 60-73)

9. İçki ve zararları (s.74-84)

10. Tehlikeli hastalıklar (s.85-98)

11. Milletin sağlığı (s.98-101)

12. Giyinmenin sıhhi şartları (s.101-105)

13. Çocuk bakımı - Hanımlar için (s. 105-114)

14. Kır, açık hava, güneş (s.115-119)

15. Bulaşık hastalıklardan korunma (s.120-123)

16. Kazalar, zehirlenmeler, hayvan 1sırmaları (s.124-128)

İlgörel'e göre Millet Mekteplerinin en önemli dersi Yurt Bilgisiydi. ${ }^{87} 1$ Mart 1923'te TBMM'nin yasama yılı açılış konuşmasında Mustafa Kemal Paşa, basit ifadeli ve

86 Muhittin Celal, Millet Mektepleri ile Halk Dershanelerine Mahsus Sağllk Bilgisi, İstanbul, Şirketi Mürettebiye Matbaas1, 1930. (Eserde yazar adı Doktor Muhittin Celal olarak geçmektedir.)

87 Mücteba İlgürel, Millet Mektepleri (Doğumunun 100. Yılında Atatürk'e Armağan), s.33. 
uygulanabilir tarzda bir "Devlet Kitabı" hazırlanmasını ve halkın bilgilendirilmesini istemişti. ${ }^{88}$ Cumhuriyetin ilanından sonra bu konu ile ilgili olarak, Maarif Vekâleti bütün okullara bir genelge göndererek, çeşitli derslerde (Malumat-1 Hukukiye, Malumat-1 Medeniye, Hukuk ve Tarih gibi) cumhuriyet esaslarının öğrencilere iyice kavratılmasını istemişti. ${ }^{89}$ Yurt bilgisi ders kitabının bu taleplere uygun olduğu düşünülmektedir.

Yurt Bilgisi dersinin amacı, talebeye vatan, millet vatandaşlık hak ve vazifeleri hakkında bir vatandaşın bilmesi gereken asgari malumatı kazandırmaktı. Yurt Bilgisi dersinde işlenen konular şöyledir: ${ }^{90}$

- Türk Bayrağ1; Türk bayrağının dalgalandığı yerler: Türkiye, Türkiye’nin hudutları: Türkler, nüfusumuz.

- Türk milletinin eskiliği; eski zamanlarda Türk devletleri; Yeni Türk Cumhuriyetinin kuruluşu; Sultanlar istibdadının neticeleri; Büyük harp, Türkiye'nin düşmanlar tarafından istilası; İstiklal kavgası; Büyük Gazinin hizmetleri; Türk istiklal ve hürriyeti; Teşkilat-1 Esasiye kanununun esas maddeleri.

- Büyük Millet Meclisi; milletvekili seçimi; cumhurbaşkanı; vekiller; vilayetler ve kazalar; belediye teşkilatı ve meclis-i umumi ve belediye seçimleri.

- Vergiler, askerlik.

- Mahkemeler.

- Hükümete nasıl müracaat edilir: dilekçe.

- İyi bir Türk vatandaşı: vatanını sever, Milletini sever, vazifesini bilir, çalışır, insaniyetlidir.

- Türk Milli bayramları ve manaları: 23 Nisan, 23 Temmuz, 29 Teşrinievvel, 31 Ağustos.

Bu derste, İbrahim Hilmi’nin "Millet Mekteplerine ve Halka Mahsus Yurt Bilgisi” adlı eseri okutulmuştu. Kitabın konu planı, talimatnamedeki içeriğe paralel olarak hazırlanmış, sade ve anlaşılır bir dil kullanılmıştı.

88 Şaban Ortak, “Atatürk Dönemi Eğitim Politikalarında Yabancı Uzman Raporlarının Etkileri,” Yayınlanmamış Doktora Tezi, Atatürk Üniversitesi Atatürk İlkeleri ve İnk1lap Tarihi Enstitüsü Müdürlüğü, Erzurum, 2004, s.18.

89 Şaban Ortak, "Atatürk Dönemi Eğitim Politikalarında Yabancı Uzman Raporlarının Etkileri”, s. 18

90 BCA, 490-1-0-0-1-3-12. 
Kitabın giriş kısmında maksat; "Talebeye vatan, millet, vatandaşlık hak ve vazifeleri hakkında bir vatandaşın bilmesi lazım olan asgari malumatı kazandırmaktır”; şeklinde ifade edilmişti. ${ }^{11}$

Kitaba göre iyi vatandaş, yurdunu çok iyi tanıyan, vatan ve hürriyet aşkı duyan, adalete saygı duyan, memleketin kanunlarına uyan, aile ve vatandaşlarına karşı her an fedakârlık yapmaya hazır bulunan insana denir. Vatandaşlık hak ve vazifesi de ancak Yurt Bilgisi okumakla öğrenilir.92

Cumhuriyet idaresi, bütün kuvveti halka bırakan, bütün halkın istediği, en iyi yönetim şekli olarak tanttılıyor. ${ }^{93}$ Teşkilatı Esasiye Kanunu için, "Bu kanun Cumhuriyetin ruhudur. Her Türk vatandaşı bu kanunu bilmelidir. Çünkü bu kanun bize hürriyet, müsavat, adalet, serbest çalışma, düşünme, malımıza sahip olma ve saire gibi birçok umumi haklar vermiştir. Bu hakların kıymetini bilelim. Cumhuriyet idaresinin faziletlerini anlayalım" ifadelerine yer veriliyor. ${ }^{94}$

Eserde Türklerin genel ve siyasi hakları şöyle sıralanmıştır: özgürlük, eşitlik, mesken masuniyeti, vicdan hürriyeti, düşünce ve neşir hürriyeti, seyahat hürriyeti, çalışma ve iş hürriyeti, mülk edinme ve tasarruf etme hak ve hürriyeti, şirket teşkili hakkı, toplanma ve cemiyet teşkili hakk1. ${ }^{95}$

Bu bilgilerden sonra Teşkilatı Esasiye kanununun ana fikirleri sıralanıyor: hâkimiyet milletindir, Türkler kanun karşısında eşittir, her Türk hürdür, herkes düşündüğünü söyler ve yazar, bütün Türkler okuma yazma bilmeye mecburdur. ${ }^{96}$

\section{Millet Mekteplerinin Halk Eğitimine Katkısı}

Eğitim Cumhuriyetin kuruluşundan beri önde gelen sorunlardan biri olmuştu. Ankara hükümeti, henüz Kurtuluş Savaşı sırasında cephelerde çarpışmalar devam ederken ve savaşın gidişatı henüz belli değilken bile 1921 yılında Millî Eğitim Şûrası toplayarak eğitime verdiği önemi göstermişti. ${ }^{97}$ Ülkedeki okuryazar oranının çok düşük olması sebebiyle halk eğitimi konusu da ayrı bir öneme sahipti.

91 İbrahim Hilmi, Millet Mektepleri ile Halk Dershanelerine Mahsus Yurt Bilgisi, İstanbul, Marifet Matbaası, 1931., s.2.

92 İbrahim Hilmi, Millet Mektepleri ile..., s.4.

93 İbrahim Hilmi, Millet Mektepleri ile..., s. 46-47.

94 İbrahim Hilmi, Millet Mektepleri ile, s. 48.

95 İbrahim Hilmi, Millet Mektepleri ile, s.50-54.

96 İbrahim Hilmi, Millet Mektepleri ile..., s.52-53.

97 Cemal Avc1, "Harf İnkılabı ve Millet Mektepleri”, s.43 
“Cumhuriyet döneminin başında öğretmenler ve onların meslekî kuruluşları kentlerde, köylerde, Irşad Heyetleri (aydınlatma toplulukları) adı altında halkı aydınlatma çalışmaları yapmışlar, halka devrimlerden bahsetmişler, okuma yazma öğretmişlerdir (1925-1928)." 98

"Maarif Vekili Necati Bey, eğitim alanında yapacağı çalışmaları anlatmak için 8 Şubat 1926'da yaptığı basın toplantısında; halkın eğitimine yönelik olarak, Halk Dershaneleri, Halk Kütüphaneleri açılacağını, konferanslar düzenleneceğini ve sinemalar kurulacağını açıklamıştır." "99 İlerleyen dönemde de Milli Eğitim Bakanlığı ülkedeki cehaletin önüne geçebilmek ve okuma-yazma oranını artırabilmek amacıyla bakanlık bünyesinde Halk Eğitimi birimini kurmuş ve ilk defa 1927 yılında Halk Dershaneleri’ni faaliyete geçirmişti. Bu dershaneler Harf İnkılabından sonra yeniden düzenlenerek Millet Mektepleri adı altında teşkilatlanmıştı. ${ }^{100}$

Millet Mekteplerinin asıl kuruluş amacı yeni Türk alfabesini halka öğretmek ise de ilk yıldan itibaren Millet Mekteplerinin Halk Eğitimine dolaylı da olsa bir katkı sağlama amacı taşıdığ 1 gözlenmektedir. İlk talimatnamede A ve B sınıflarını bitirenlerin 28 Mayıs 1928 tarihli Halk Dershaneleri nizamnamesine uygun olarak gerekli mesleki ve fenni bilgileri edinmek, gerekli uygulamayı yapmak ve üretim kabiliyetini arttırmak amacıyla, açılacak dil, ticaret ve sanat dershanelerine devam edecekleri belirtilmişti. Millet Mekteplerini tamamlamak Halk Dershanelerine katılmak için ön koşul olarak belirlenmişti. ${ }^{101}$ İkinci dönemden itibaren ise doğrudan bu amaca yönelik bir faaliyete girilmiş, halka bazı temel bilgilerin kazandırılması istenmişti.

98 Yahya Akyüz, Türk Eğitim Tarihi, s.404.

99 Şaban Ortak, “Atatürk Dönemi Eğitim Politikalarında Yabancı Uzman Raporlarının Etkileri”, s.124

100 Cemal Avc1, “Harf İnk1lab1 ve Millet Mektepleri”, s.53 (Not: Halk Dershaneleri, 1927'de kurulan, Millet Mektepleriyle benzerlik gösteren bir halk eğitimi kurumudur. Halk dershaneleri, mecburi tahsil yaşını geçirdiği halde okumamış yahut istediği terbiye veya tahsil derecesine erişememiş olanlara mahsus olup isteğe bağlı ve parasız bir halk eğitimi kurumudur. Halk dershanelerinde, halka muhtaç olduğu mesleği ve fenni bilgileri vermek, icap eden tatbikatı yaptırmak ve bu suretle halkın istihsal kudretini arttırmak maksadıyla, imkân görülen yerlerde, geçici veya daimî olmak üzere lisan, ticaret ve sanat kursları veya dershaneleri açılır (madde 7). İlk halk dershanelerinde tedrisat terbiyevi esaslara dayanır, medeni hayata ve milli harsa intibak edecek tarzda icra edilir. Derslerin mümkün olduğu kadar somut (müşahhas) ve uygulamalı olmasına çalışılır. Bu hususta sinema, projeksiyon, tablo ve saire gibi somut (mücessim) ve cazip vesaitten ve ayrıca çeşitli eğitim araçlarından faydalanılır. İlk halk dershanelerinde ana dili öğretilir. Milliyet ve cumhuriyet prensipleri dairesinde kuvvetli bir terbiye verilir. Vatani, tarihi, coğrafi, sıhhi, zirai, ticari ve iktisadi bilgiler temin edilir. Kadınlara mahsus dershanelerde ayrı bir dikiş ve nakış dershanesi mevcut olmadığı takdirde dikiş ve nakış da öğretilir. Ev idaresine ve çocuk bakımına ait malumat verilir (madde 14). (T.C. Resmî Gazete, Say1:943, 19 Temmuz 1928, s.5544-5546)

101 T.C. Resmî Gazete, Say1:1048, 24 Kasım 1928. 
Millet Mektepleri başarılı olmuş mudur? Bu çalışma sırasında Millet Mekteplerinin alfabenin duyurulması ve tanıtılması konusunda başarılı, okuryazar oranına katkısı açısından ise kısmen başarılı olduğu gözlenmiştir.

Coşkulu açılış törenleri, önde gelen devlet görevlilerinin bu törenlere katılması ve Millet Mekteplerinin iktidar ve basın tarafından desteklenmesiyle Millet Mekteplerinin en çok yeni alfabenin halka bildirilmesi ve tanıtılması konusunda katkı sağladığı söylenebilir.

Millet Mektepleriyle okuma yazma sorunu tamamen çözülememiş olsa da ilk yılda verilen yüksek mezun sayısı yeni alfabenin iki ve dört aylık dönemlerle hızlı ve kolayca öğrenilebildiği mesajını vererek yeni alfabenin kolayca öğrenilebileceğine dair bir veri oluşturmuştur.

Sayısal olarak bir değerlendirme yapılırsa kısmi bir başarıdan söz edilebilir. İsmet Paşa'nın sözlerine göre, Millet Mektepleri henüz faaliyete geçmeden önce bu teşkilat sayesinde bir senede, vatandaşın iş hayatındaki düzenini hiç sarsmaksızın ileri yaşlarda birkaç yüz bin nüfusun okutulabileceği hesap ediliyordu. ${ }^{102} \mathrm{Bu}$ cümle esas alınırsa Millet Mekteplerinin sayısal anlamda sadece ilk iki sene başarılı olduğu söylenebilir. Tabloda da görüldüğü gibi ilk sene kursa devam eden ve başarılı olanların sayısı 526,851 iken ikinci sene bu sayı 245,663'tü. Sonrasında ise sayı ciddi oranda azalmaktadır.

Yine aynı tabloya göre dershaneye devam edenlerle dershaneye devam edenlerden başarılı olanların oranı karşılaştırılırsa başarı oranının yüzde elli olduğu dikkati çekmektedir. Katılımcıların başarı oranı düşük görülmektedir. 


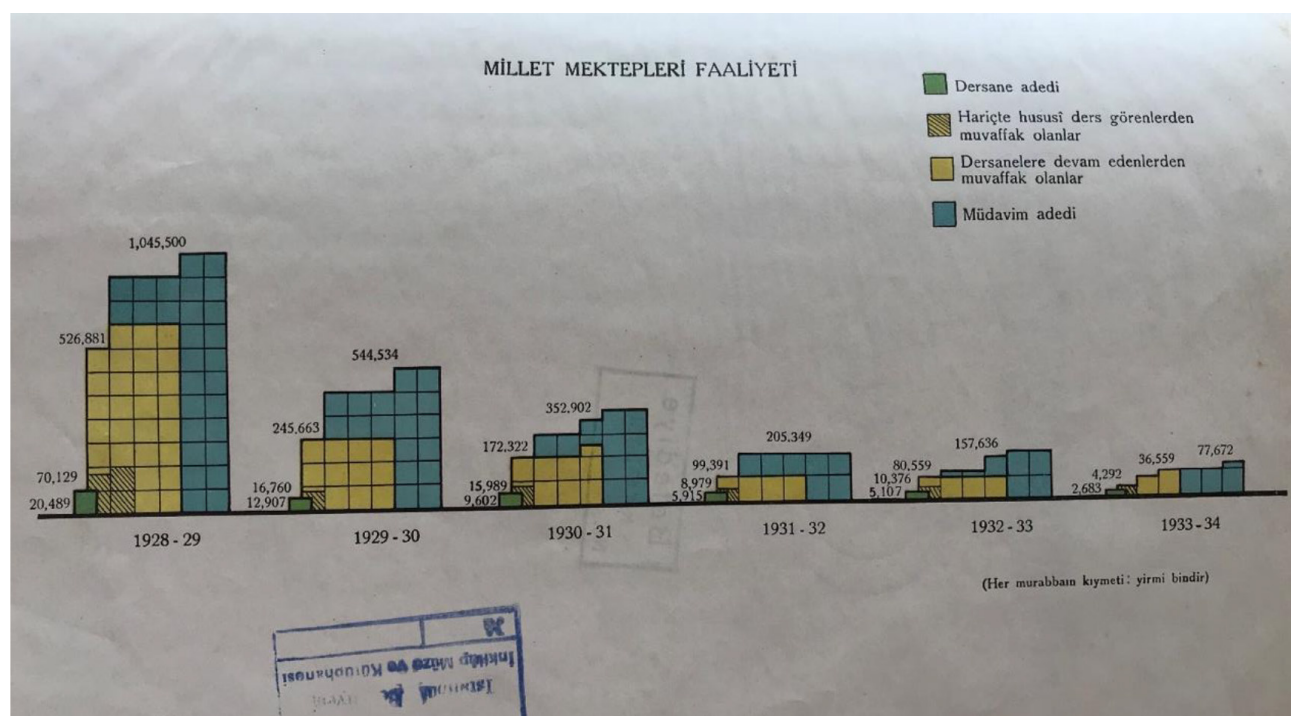

Tablo 1: Millet Mektepleri Faaliyet İstatistiğ ${ }^{103}$

İstatistiki olarak yeterince veri olmadığı için nüfus üzerinden kaba bir hesap yapılırsa sonuç olumlu görülmektedir. Millet Mektepleri sadece tahsil çağını geçirmiş halk kitlesini hedef almıştı ve devlet dairelerinde görevli memurlar çeşitli kurslarla yeni harfleri öğrenmiş ve 12 Kasım 1928'den itibaren imtihanlara girmişti. ${ }^{104}$ Dolayısıyla hedef kitleden Millet Mektepleri öncesi yeni alfabeyi öğrenen kişilerin çıkarılması gerekmektedir. 1928-1933 istatistiğinin önsözündeki bilgiler de dikkate alınmıştır. Buna göre istatistikler sadece Millet Mekteplerinden mezun olanların miktarını gösterir. Türk harfleriyle okuyup yazma bilenlerin toplamı kitapta görülen sayının $(1,247,149)$ üç dört misli fazladır. Çünkü Millet Mektepleri dışında Türk harfleriyle okuma yazma öğrendiği kesin olan toplamı yüz bini geçen devlet, özel idare ve belediye memurlarıyla on sekiz bin küsur öğretmen ve yeni harflerin yürürlüğe girdiği sene tüm okullarda mevcut yarım milyondan fazla öğrenci, ordu ve jandarma görevlisi, orduda okuma öğrenen yüzbinlerce kura efradı, tüm bankalar ve benzeri kurumlar ve şirket çalışanları ayrıca halk arasında kendi kendisine okuma yazma öğrenenler bu toplama dahil değildir. Türk harfleriyle okuma yazma bilenlerin toplamı en küçük bir hesapla 3 milyonu geçer. ${ }^{105}$ 1927 nüfus sayımında Türkiye nüfusu 13,6 milyon kişi iken, 1935’te 16,1 milyon kişiye

103 Başvekâlet İstatistik Umum Müdürlüğü, Maarif 1928-1934 Millet Mektepleri Faaliyeti İstatistiği, Neşriyat No:51, Devlet Matbaas1, İstanbul, 1934, s.50.

104 Mücteba İlgürel, Millet Mektepleri...,s.28.

105 Başvekâlet İstatistik Umum Müdürlügü̈, Maarif 1928-1934 Millet Mektepleri Faaliyeti İstatistiği, Neşriyat No:51, İstanbul, Devlet Matbaas1, 1934. 
yükselmiştir. ${ }^{106} 1927$ sayımında 20-45 yaş arası nüfus 4,949,520 iken 7-19 yaş arası 3,422,656'dır. ${ }^{107} 7-19$ yaş arası nüfustan, yani yaklaşık 3,5 milyon kişiden ne kadarının 16 yaş ve üstü olduğu bilinmemektedir. Bu rakamlar dikkate alınırsa Millet Mekteplerinin 1,2 milyon mezun vermesi (1934'e kadar) başarı olarak görülmelidir.

Katılımcı sayısının giderek azaldığı hükümetin de farkında olduğu bir gerçekti. 1932'de Mahmut Esat Bey Millet Mekteplerine devam eden vatandaşların seneden seneye miktarlarının azalma nedeninin bir kısım vatandaşların "B” kurslarında da meşgul olmalarından meydana geldiğini söylemekteydi. ${ }^{108}$

Mücteba İlgürel'e göre Millet Mektepleri tam manasıyla hedefine ulaşamamıştı, aç1lışlardan bir süre sonra devam eden öğrenci sayısında düşüş olmuştu. Ayrıca imtihanlara girenlerin seviyelerinde de bir düşme olduğu ve bunun öğrenciler üzerinde olumsuz etki yarattı̆̆ anlaşılmıştı. ${ }^{109}$

Bir başka görüşe göre de, 1929 ekonomik buhranının da etkisiyle gündemdeki yerini kaybeden Millet Mektepleri Türkiye'nin aydınlanma sürecinde belirlenen hedeflere ulaşılamamış olsa da, Harf devriminin toplumda tutunması sağlanarak önemli bir işlev yerine getirmişti. ${ }^{110}$

1929 ekonomik buhranı yanında, Osmanlı borçlarının ödenmeye başlanacak olması, CHF'nin yerel yönetimde düzeyinde çok iyi örgütlenememiş olması, Millet MektepleriHalkevleri iş birliğinin yeterince sağlanamamış olması, Necati Bey’in vefatı, yetişkinlerin eğitiminde kullanılacak olan çalışma yöntemlerinin yeterince bilinmemesi Millet Mekteplerinin başarısının sürdürülememesinin bazı etkenleri arasındaydı. ${ }^{111}$

Etkinlikleri giderek azalsa da ilk 5 yıl içinde bu okullardan bitirme belgesi alanların 1,217,144'e ulaşması küçümsenemeyecek bir başarının göstergesidir. ${ }^{112}$

Millet Mektepleri sayesinde halk eğitiminde daha güçlü bir kurumsallaşmaya gidildiği de söylenebilir. 1929 yılında Millet Mektepleri kapsamı, seyyar ve sabit Millet

106 Ali Çiftçi, “Türkiye’nin Nüfus Bilgileri Işı̆̆ında Kazım Karabekir’in Aile ve Nüfus Politikalarına İlişkin Görüşleri ve Bugünkü Durum”, Aile ve Toplum, Y.11, C.5, S.19, Kasım-Aralık 2009, s.27.

107 Mustafa Köse, “1927 Nüfus sayımı ve Sonuçlarının Değerlendirilmesi”, Yayınlanmamış Yüksek Lisans Tezi, Afyon Kocatepe Üniversitesi, Sosyal Bilimler Enstitüsü Tarih Anabilim Dalı, Afyonkarahisar, 2010, S.179

108 TBMM Zabit Ceridesi, D.IV, İ.S. LXX, C. IX, (25 Haziran 1932), s.321.

109 Mücteba İlgürel, Millet Mektepleri..., s.34

110 Saime Yüceer, “Türkiye’nin Aydınlanma Sürecinde Bir Kültür Devrimi Millet Mektepleri”, Atatürkçü Bakış Dergisi, Uludağ Üniversitesi, C. 1, S.1, 2002, s.32

111 Mustafa Şahin, "Bir Halk Eğitim Çalışması Örneği Olarak Millet Mektepleri”, Çağdaş Türkiye Tarihi Araştırmaları Dergisi, C. 1, S.2, Ocak 1992, s.231-232.

112 Şerafettin Turan, Türk Devrim Tarihi 3..., s.213. 
Mektepleri A ve B dershaneleri, halk okuma odaları ve köy yatı dershaneleri olarak genişletilmişti (m.2). ${ }^{113}$

Halk Okuma Odalarıyla halkın okuma yazma alışkanlığı kazanması ve okuma araçlarına kolayca ve ücretsiz olarak erişebilmesi amaçlanmıştı. Bu çalışmalarla halkın okuma gereçlerine ücretsiz ulaşımı sağlanmıştı.

Maarif idaresi Halk okuma odaları ile ilgili Kasım 1929'da tetkikat yapmış ve Halk odalarının açılacağı yerler tespit edilmişti. ${ }^{114}$ Kasım 1930'da her tarafta arttırılan okuma odalarının miktarı 5100'e varmıştı. ${ }^{115} 21$ Eylül 1930 Tarihindeki haberde ise bu say1 1350'dir. Aynı habere göre Maarif Vekâleti 11500 lira masrafla 5691 kitap alarak okuma odalarına dağıtmıştı. ${ }^{116}$ İstanbul'da da Halk okuma teşkilatı etrafındaki faaliyet gittikçe gelişmekteydi. Maarif idaresi Selçuk Hatun ve kız sanayi mekteplerinde de gece kursları açmıştı. ${ }^{117}$ Maarif vekâleti ikinci Millet Mektepleri talimatnamesi ile kabul edilen Halk okuma odaları hakkında yeni bir rehber de yayınlamıştı. Vekâlet bu rehbere ilave ettiği bir mukaddemede Halk Okuma Odalarının amacını ve faydalarını etraflıca izah etmektedir. On yedi maddelik rehberde odaların oluşturulma ve idare şekli tayin edilmiştir. ${ }^{118}$

1929 talimatnamesi kitapçığında ayrıca Köy Yatı Dershaneleri hakkında bir bölüm de yer almaktadır. Köy Yatı Dershanelerinin seyyar Millet Mekteplerinden farkı, yaşı 12-18 arasında olan sağlıklı ve zeki çocuklara yatılı eğitim verecek olmasıdır. ${ }^{119}$

Millet Mekteplerinin ilk devresinin bitmesinin ardından, tatil dönemi esnasında Ankara'ya mektepleri olmayan köylerden 'zeki ve on iki yaşından büyük' çocuklar getirtilerek okutuluyor; bir ay zarfinda elde edilen netice, bu sistemin mümkün olan yerleri de kapsamasını kuvvetle teşvik edecek mahiyet ve değerde görülüyor. Bu girişimin, aynı zamanda köy çocuklarının zekâları üzerinde (öğretmenlerinin rehberliğinde Ankara'daki bütün müesseseleri gezip görmeleri ve tanımaları neticesinde) çok verimli sonuçları olmuştu. Böylece 1929 talimatnamesiyle başlayacak yeni dönemde- mektepleri ve muallimleri bulunan yerlerde- bu tür dershanelerin açılması da öngörülmüştü. Bu dershaneler ve talebelerinin barınma ve yeme-içmeleri büyük bir masraf

113 T.C. Resmî Gazete, Say1 1321, 7 Ekim 1929, s.8396.

114 "Halk okuma odaları tetkikatı", İkdam, nr.11683, 4 Kasım 1929, s.2.

115 "Millet Mekteplerinde Faaliyet", Cumhuriyet, nr.2340, 11 Kasım 1930, s.4.

116 "Bu sene 12,692 dershane aç1ldı", Cumhuriyet, nr.2290, 21 Eylül 1930, s.3.

117 "Yeni dershaneler açılacak", İkdam, nr.11685,6 Kasım 1929, s.2.

118 "Okuma odaları", Milliyet, nr.1398, 2 Ocak 1930, s.6.

119 BCA, 490-1-0-0-1- 3-12. 
gerektirmemekteydi. Detaylar, Maarif Vekâletince yayınlanacak özel bir tamimle ilgililere bildirilecekti. ${ }^{120}$

Böylece Maarif teşkilatının henüz ulaşamadığı mektepsiz köylerin çocuklarını okutup köylerine iade etmek üzere Millet Mektepleri talimatnamesi hükümlerine uygun olarak "köy yatı dershaneleri tesis edilmesine karar verilmişti. Bu dershaneleri bitiren çocuklar mensup oldukları köyde bir mektep açılacağı ve bütün köy çocuklarının okutulmasına imkân sağlanacağı güne kadar mühim bir ihtiyacı giderecek ve köylerinin; muhitine faydalı okuryazar insanları olacaklard1. ${ }^{121}$

Milli Talim ve Terbiye Heyeti Dairesinde, Türkiye’ye çok faydası dokunmuş eğitime dair dikkate değer teknik bilgi ve malumat toplanmıştı. ${ }^{122}$ Millet Mektepleri sayesinde halk eğitimine dair veriler elde edilmişti. Millet Mektepleri talimatnamesiyle her sene Maarif Vekâletine Millet Mektepleri dershane, öğretmen ve katılımcı istatistikleriyle meydana gelen sayısal değişiklikler, çeşitli kurslara taksim şekilleri ve halkı okutma faaliyeti hakkındaki genel değerlendirme ile temennilerin bildirilmesi istenmişti. ${ }^{123}$ Maarif Eminleri de halkın okuma faaliyetlerini sürekli teftiş faaliyetlerinden edindikleri izlenim ve değerlendirmelerini raporlarla Maarif Vekâletine bildirirler. Ayrıca Maarif Müdürleri de Maarif eminliğine Millet Mekteplerinde cereyan eden faaliyet hakkında istatistiki bilgi de içeren iki rapor hazırlamakla yükümlüydü. ${ }^{124}$

Cumhuriyet yönetimi çağdaş uygarlık düzeyini hedeflemiş ve bu hedefe uygun toplumsal yapıyı oluşturmak adına eğitime önemli bir rol biçmişti. Harf İnkılabı ile birlikte uygulamaya konan Millet Mektepleri de, eğitimin toplumsal rolüne uygun olarak Cumhuriyet rejiminin yeni kimliğini kazanması ve yapılanmasında önemli katkılar sağladı. Okuma-yazma savaşımına sağladığı büyük katkılardan dolayı, Millet Mektepleri Türk eğitim tarihinde önemli bir yere sahiptir. ${ }^{125}$

\section{Sonuç}

Uzun zamandan beri devam eden alfabe tartışmaları 1 Kasım 1928'de yapılan Harf İnkılabıyla sonuçlandırıldı ve Türkiye'de Latin harflerine dayanan yeni bir alfabe kabul

$120 B C A, 30-18-1-2-21-46-19$.

121 BCA, 490-1-0-0-1- 3 - 12 (Millet Mektepleri Talimatnamesi ve Tatbikine Rehberlik Edecek Dahili Talimatnameler, 3. Bölüm, Köy Yatı Dersaneleri, Ankara, Köy Hocası Matbaası, 22 Eylül 1929, s.3-7)

122 T.C. Maarif Vekilliği, Amerikan Heyeti Raporundan: Maarif İşleri, T.C. MV Ana Programa Hazırlıklar, Seri: B, No:6, 1939, İstanbul, Devlet Basımevi, s.32.

123 T.C. Resmî Gazete, Say1:1321, 7 Ekim 1929, s.8398.

124 BCA, 490-1-0-0-1-3-12.

125 Selçuk Duman, Modern Türkiye’nin İnşasında Halkevleri ve Sivas Halkevi Örneği, Ankara, Berikan Yayınları, 2013 , s.49. 
edildi. Bu inkılaba bağlı olarak açılan Millet Mektepleriyle halkın yeni alfabeyi öğrenmesi, okuryazar oranının arttırılması ve halka bazı temel bilgilerin kazandırılması amaçlandı. Basının da desteğiyle Millet Mektepleri büyük bir coşkuyla tanıtıldı ve halkın büyük ilgisiyle yoğun propaganda faaliyetleri karşılığını buldu.

Millet Mektepleriyle ilgili yaygın kanı ilk yıllar büyük başarı elde ettiği ve bu başarının giderek azaldığı yani sürdürülemediği yönündedir. Durum böyle olsa da Millet Mektepleri tarih kitaplarındaki yerine de bakılarak bir kilometre taşı olarak görülmektedir. Millet Mekteplerinin Halk eğitimi konusunda ilk doruk noktası olduğu söylenebilir.

Millet Mekteplerinin sağladığı en önemli katkının Harf İnkılabının kolayca benimsenmesini sağlaması olduğu düşünülmektedir. Yeni alfabenin tanıtılmasına Sarayburnu nutku sonrası gazetelerde yer verilmekteydi, Atatürk de alfabeyi öğretmek için yurt gezilerine çıkmıştı. Ancak Millet Mektepleriyle beraber tüm ülkede aynı anda halkın da rol alacağı okuma yazma seferberliği başlamış oldu.

Millet Mektepleri katılım oranı her yıl düşmüş olsa da okuma yazma oranının artmasına yardımcı olmuştur. Sonuçta resmi olarak yaklaşık bir buçuk milyon kişi bu kurumlar aracılı̆̆ılyla okuma yazma öğrenmiştir ve bu rakam o dönemki nüfus göz önünde bulundurulursa hatırı sayılır bir rakam olarak görülebilir.

Millet Mektepleri hakkında pek çok rapor hazırlanmış, bu sayede eğitim alanında pek çok veri de toplanmıştır. Hazırlanması istenen raporlarla eğitim konusunda önemli ve derin bilgi edinilmesi sağlanmıştır. Eğitim konusundaki eksiklikler ve ihtiyaçlar belirgin şekilde ortaya konmuştur.

Halka okuma yazma öğretilirken sağlık, vatandaşlık, tarih, devletin işleyişi gibi temel konularda da vatandaşların bilgilendirilmesi sağlanmış, eğitim içeriğiyle vatandaşın kendisine verilen bilinçli vatandaş rolünü algılaması amaçlanmıştı. Halk anayasa, meclis, cumhurbaşkanı, başbakan, bakanlıklar, seçim, yerel yönetimler, devlete dilekçeyle başvuru vb. konular aracılığıyla halkın devlet kurumlarını yakından tanıması hedeflenmişti.

Millet Mekteplerinin açılışından bir süre sonra, halk odaları ve köy yatı dershaneleri açılarak halk eğitimi konusundaki örgütlenme derinleştirildi. Bu örgütlenme 1932 yılında açılacak Halkevleri ve Halkodaları için de tecrübe ve altyapı olarak görülebilir. Bunların yanında yeni cumhuriyet kimliğine katkısı da küçümsenmeyecek derecededir. 
Hakem Değerlendirmesi: Dış bağımsız.

Çıkar Çatışması: Yazar çıkar çatışması bildirmemiştir.

Finansal Destek: Yazar bu çalışma için finansal destek almadığını beyan etmiştir.

Peer-review: Externally peer-reviewed.

Conflict of Interest: The author has no conflict of interest to declare.

Grant Support: The author declared that this study has received no financial support.

\section{KAYNAKÇA}

\section{Arşiv Belgeleri ${ }^{126}$}

Türkiye Cumhuriyeti Cumhurbaşkanlı̆̆ Devlet Arşivleri Başkanllğı Cumhuriyet Arşivi $(B C A)$

\section{Süreli Yayınlar ${ }^{127}$}

Cumhuriyet

İkdam

Milliyet

Son Saat

\section{Resmî Yayınlar}

\section{TBMM Zabit Ceridesi}

\section{T.C. Resmî Gazete}

Maarif 1928-1934 Millet Mektepleri Faaliyeti İstatistiği, Başvekâlet İstatistik Umum Müdürlüğ̈̈, Neşriyat No:51, İstanbul, Devlet Matbaas1, 1934.

T.C. Maarif Vekilliği, Amerikan Heyeti Raporundan: Maarif Işleri, T.C. MV Ana Programa Hazırlıklar, Seri: B, No:6, 1939, İstanbul, Devlet Basımevi, 1939.

\section{Araştırma Eserler}

Akyüz, Yahya: Türk Eğitim Tarihi M.Ö. 1000 - M.S. 2015, Ankara, Pegem Akademi, 2015.

Atay, Falih Rıfkı: Çankaya, İstanbul, Pozitif Yayınları, 2009.

Avc1, Cemal: "Harf İnkılabı ve Millet Mektepleri", Mediterranean Journal of Humanities Akdeniz İnsani Bilimler Dergisi, Akdeniz Üniversitesi, III/1, 2013, s.43-60.

126 Faydalanılan arşiv kaynaklarına ait detaylı bilgiler dipnotlarda belirtilmiştir.

127 Faydalanılan süreli yayınların sayı, makale/haber başlığı ve sayfa numaraları dipnotlarda belirtilmiştir. 
Başgöz, İlhan: Türkiye 'nin Eğitim Çıkmazı ve Atatürk, 3. Baskı, İstanbul, Pan Yayıncılık, 2004.

Berkes, Niyazi: Türkiye'de Çağdaşlaşma, 7. Baskı, YKY, İstanbul, YKY, 2005.

Çiftçi, Ali: “Türkiye'nin Nüfus Bilgileri Işı̆̆ında Kazım Karabekir'in Aile ve Nüfus Politikalarına İlişkin Görüşleri ve Bugünkü Durum”, Aile ve Toplum, Yı1:11, C.5, S.19, Kasim-Aralik 2009, s.25-39.

Duman, Selçuk: Modern Türkiye'nin İşasında Halkevleri ve Sivas Halkevi Örneği, Ankara, Berikan Yayınları, 2013.

İlgürel, Mücteba: Millet Mektepleri (Doğumunun 100. Yılında Atatürk'e Armă̆an), Ayr1 basım, İstanbul, İstanbul Üniversitesi Edebiyat Fakültesi Matbaası, 1981.

Kılıç, Fahri: Yeni Türk Alfabesinin Kabulü ve Öğretimde Kullanılan Yöntemler-Araçlar Ankara Üniversitesi Türk İnkılap Tarihi Enstitüsü Yayınlanmamış Doktora Tezi, Ankara, 2011.

Kıroğlu, Yasemin: Harf İnkılâbı'nın Atatürk Devrimlerinin Yayılmasına Etkisi, Marmara Üniversitesi Türkiyat Araştırmalarl Enstitüsü Atatürk İlkeleri ve İnklap Tarihi Anabilim Dalı, Yayınlanmamış Yüksek Lisans Tezi, İstanbul, 2008.

Köse, Mustafa: 1927 Nüfus Sayımı ve Sonuçlarının Değerlendirilmesi, Afyon Kocatepe Üniversitesi, Sosyal Bilimler Enstitüsü Tarih Anabilim Dalı, Yayınlanmamış Yüksek Lisans Tezi, Afyonkarahisar, 2010.

Lewis, Bernard: Modern Türkiye’nin Doğuşu, çev. Metin Kıratlı, 7. Bask1, Ankara, Türk Tarih Kurumu Yayınları, 1998.

Muhittin Celal: Millet Mektepleri ile Halk Dershanelerine Mahsus Săglık Bilgisi, İstanbul, Şirketi Mürettebiye Matbaası, 1930.

Ortak, Şaban: Atatürk Dönemi Eğitim Politikalarında Yabancı Uzman Raporlarının Etkileri, Atatürk Üniversitesi Atatürk Illkeleri ve Inkılap Tarihi Enstitüsü Müdürlüğü, Yayınlanmamış Doktora Tezi, Erzurum, 2004.

Şahin, Mustafa: “Bir Halk Eğitim Çalışması Örneği Olarak Millet Mektepleri”, Çă̆daş Türkiye Tarihi Araştırmaları Dergisi, C.1, S.2, Ocak 1992, s.213-234.

Turan, Şerafettin: Türk Devrim Tarihi 3. Kitap (Birinci Bölüm) Yeni Türkiye’nin Oluşumu (1923-1938), 3. Bask1, Ankara, Bilgi Yayınevi, 2013.

Uluskan, Seda Bayındır: Atatürk'ün Sosyal ve Kültürel Politikalarl, Ankara, Atatürk Araştırma Merkezi Yayını, 2010.

Yalçın, Durmuş vd.: Türkiye Cumhuriyeti Tarihi II, 9. Baskı, Ankara, Atatürk Araştırma Merkez, 2012. 
Yorulmaz, Hüseyin (yay. haz.): Tanzimat'tan Cumhuriyet'e Alfabe Tartışmalar1, İstanbul, Kitabevi, 1995.

Yüceer, Saime: “Türkiye'nin Aydınlanma Sürecinde Bir Kültür Devrimi Millet Mektepleri”, Atatürkçü Bakış Dergisi, Uludağ Üniversitesi, C.1, S.1, 2002, s.13-32. 